\title{
Comorbidities increase the risk of severity and mortality in COVID-19 patients: a
}

\section{systematic review and meta-analysis}

Comorbidades aumentam o risco de gravidade e mortalidade em pacientes com COVID-19: uma revisão sistemática e metanálise

Comorbilidades aumentan el riesgo de gravedad y mortalidad en pacientes con COVID-19: una revisión sistemática y metanálisis

Edilson Leite de Moura

ORCID: https://orcid.org/0000-0001-6216-6522 Universidade Federal de Alagoas, Brasil E-mail: edilsonleite17@hotmail.com

Jean Moises Ferreira

ORCID: https://orcid.org/0000-0002-6554-0337

Universidade Federal de Pernambuco, Brasil

E-mail: jean.moises@hotmail.com

Ana Caroline Melo dos Santos

ORCID: https://orcid.org/0000-0003-0280-6107

Universidade Federal de Alagoas, Brasil

E-mail: anacaroline12305@gmail.com

Denise Macedo da Silva

ORCID: https://orcid.org/0000-0002-2294-6660 Universidade Federal de Alagoas, Brasil E-mail: denise.macedo15@hotmail.com

Maria Lidiane Ferreira da Silva ORCID: https://orcid.org/0000-0002-4679-1069 Universidade Federal de Alagoas, Brasil E-mail: lidianebiologia2018@gmail.com

Gleyce Kelly Marques de Oliveira Silva ORCID: https://orcid.org/0000-0003-1650-1718 Universidade Federal de Alagoas, Brasil E-mail: gleycekelly1844@gmail.com Pedro Henrique Nobre Silva

ORCID: https://orcid.org/0000-0003-1994-6480 Universidade Federal de Alagoas, Brasil E-mail: pehnobre@gmail.com

José Anderson dos Santos ORCID: https://orcid.org/0000-0002-4182-4693 Universidade Federal de Alagoas, Brasil

E-mail: jose.anderson.s.2013@gmail.com

Marcos Antônio da Silva Barbosa Junior ORCID: https://orcid.org/0000-0002-7759-4981

Universidade Federal de Alagoas, Brasil

E-mail: marcosantoniojunior.s15@gmail.com

Abel Barbosa Lira Neto

ORCID: https://orcid.org/0000-0001-7597-3761 Universidade Federal de Alagoas, Brasil. E-mail: abel.neto@arapiraca.ufal.br Aline Cristine Pereira e Silva ORCID: https://orcid.org/0000-0002-9620-5654 Universidade Federal de Alagoas, Brasil

E-mail: aline_ufal@yahoo.com.br

Carlos Alberto de Carvalho Fraga ORCID: https://orcid.org/0000-0002-9564-9595 Universidade Federal de Alagoas, Brasil E-mail: carlos.fraga@ arapiraca.ufal.br

Karol Fireman de Farias

ORCID: https://orcid.org/0000-0003-1352-2513 Universidade Federal de Alagoas, Brasil E-mail: karolfireman@hotmail.com 
Elaine Virginia Martins de Souza Figueiredo ORCID: https://orcid.org/0000-0001-9724-5861 Universidade Federal de Alagoas, Brasil E-mail: elainevms@yahoo.com.br

\begin{abstract}
Introduction: Several studies have shown that patients with comorbidities present a poor clinical outcome of COVID19 , but the conclusions are not yet consolidated. We conducted a meta-analysis to evaluate the relationship between the preexistent conditions (comorbidities) in patients infected with SARS-CoV-2 and the outcome of COVID-19. Methods: PubMed, Science Direct, ISI Web of Science and Scopus databases were examined up to November 2020. We calculated the pooled odds ratio (OR) with $95 \%$ confidence interval, using fixed-effects or random-effects models. Results: A total of 48 retrospective cohort studies with 344,290 COVID-19 patients were included in the metaanalysis. The pooled results showed that hypertension, diabetes, cardiovascular, chronic pulmonary, chronic kidney and cerebrovascular diseases increase the risk of severity and mortality in COVID-19 patients. Moreover, malignancy was associated with an increased risk of death from COVID-19. Conclusions: The comorbidities previously mentioned may be important predictors of poor outcome of COVID-19, contributing to the prognosis of severe cases of the disease. (TNR font 10 - simple space)
\end{abstract}

Keywords: Coronavirus; Comorbidities; Chronic disease; COVID-19 and SARS-CoV-2.

\begin{abstract}
Resumo
Introdução: Vários estudos têm mostrado que pacientes com comorbidades apresentam um pobre desfecho clínica da COVID-19, mas as conclusões ainda não estão consolidadas. Nós conduzimos uma metanálise para avaliar a relação entre as condições preexistentes (comorbidades) em pacientes infectados com SARS-CoV-2 e o desfecho da COVID19. Métodos: Os bancos de dados PubMed, Science Direct, ISI Web of Science e Scopus foram examinados até novembro de 2020. Nós calculamos o odds ratio (OR) com intervalo de confiança de $95 \%$, usando modelos de efeitos fixos ou aleatórios. Resultados: Um total de 48 estudos de coorte retrospectivos com 344.290 pacientes com COVID19 foram incluídos na metanálise. Os resultados combinados mostraram que hipertensão, diabetes, doenças cardiovasculares, pulmonares crônicas, renais crônicas e cerebrovasculares aumentam o risco de gravidade e mortalidade em pacientes com COVID-19. Além disso, a malignidade foi associada a um risco aumentado de morte por COVID-19. Conclusões: As comorbidades citadas anteriormente podem ser importantes preditores de pobre desfecho da COVID-19, contribuindo para o prognóstico de casos graves da doença.
\end{abstract}

Palavras-chave: Coronavírus; Comorbidades; Doenças crônicas; COVID-19 e SARS-CoV-2.

\title{
Resumen
}

Introducción: Varios estudios han demostrado que los pacientes con comorbilidades presenten un mal pronóstico clínico de COVID-19, pero las conclusiones aún no están consolidadas. Realizamos un metanálisis para evaluar la relación entre las condiciones preexistentes (comorbilidades) en pacientes infectados con SARS-CoV-2 y el resultado de COVID-19. Métodos: Se examinaron las bases de datos PubMed, Science Direct, ISI Web of Science y Scopus hasta noviembre de 2020. Nosotros calculamos el odds ratio (OR) con un intervalo de confianza del 95\%, utilizando modelos de efectos fijos o de efectos aleatorios. Resultados: Se incluyeron en el metanálisis un total de 48 estudios de cohorte retrospectivos con 344,290 pacientes con COVID-19. Los resultados combinados mostraron que la hipertensión, la diabetes, las enfermedades cardiovasculares, pulmonares crónicas, renales crónicas y cerebrovasculares aumentan el riesgo de gravedad y mortalidad en los pacientes con COVID-19. Además, la malignidad se asoció con un mayor riesgo de muerte por COVID-19. Conclusiones: Las comorbilidades mencionadas anteriormente pueden ser importantes predictores de mala evolución del COVID-19, contribuyendo al pronóstico de los casos graves de la enfermedad.

Palabras clave: Coronavirus; Comorbilidades; Enfermedades crónicas; COVID-19 e SARS-CoV-2.

\section{Introduction}

In December 2019, an outbreak that started in Wuhan - China, gave rise to Coronavirus disease 2019 (COVID-19) (Lin et al., 2020a; Tian et al., 2020a). COVID-19 is caused by Severe Acute Respiratory Syndrome Coronavirus 2 (SARSCoV-2). SARS-CoV-2 shows a high transmission capacity and infected patients may be asymptomatic or develop a moderate (non-severe) to severe form of the disease (Lai et al., 2020; Tay et al., 2020).

The clinical conditions of patients may change rapidly, leading to severe pneumonia and, eventually, to acute respiratory distress syndrome, septic shock and/or multiple organ failure, which lead to a considerable number of deaths (Alhazzani et al., 2020; Moccia et al., 2020; Moore et al., 2020). COVID-19 mortality is a serious global problem today. 
Several researches are focused on the development of vaccines and medicines, and recent discoveries may make treatment and prophylaxis a reality for the very near future (Abd El-Aziz \& Stockand, 2020; Robson, 2020). Thus, understanding the dynamics of the virus, as well as the tendency of patients to develop a poor prognosis, is vital, and this information may provide better patient care and effectively reduce the mortality of the disease (Azkur et al., 2020; Zheng et al., 2020b).

Analysis of COVID-19 patients showed that susceptibility to severe SARS-CoV-2 infection varies between different groups of patients (Lee et al., 2020; Shi et al., 2020b). Some studies have shown that pre-existing conditions before symptomatic SARS-CoV-2 infection increase the severity of the disease, leading to poor patient prognosis (Li et al., 2020d; Yang et al., 2020a). Hypertension, chronic obstructive pulmonary disease (COPD), malignancy, diabetes, cardiovascular, renal, liver and cerebrovascular diseases have been described as possible factors of severity in patients with COVID-19 and in cases of fatality (Yang et al., 2020a; Yang et al., 2020c).

The literature on SARS-CoV-2 and COVID-19 has grown and changed rapidly in response to the need for new data on the virus (Harwood \& Sinha, 2020; Lin et al., 2020b; Rando et al., 2020). For this reason, we performed a meta-analysis to affirm the relationship between pre-existing conditions (comorbidities) in patients infected with SARS-CoV-2 and the outcome of COVID-19. (TNR font 10 - justified - space 1,5).

\section{Methodology}

\subsection{Search Strategy}

To assess the association of pre-existing comorbidities with the severity and mortality of COVID-19, we performed a systematic review with a quantitative approach (meta-analysis), in which analyze the pooled data of the articles included (de Moura et al., 2020; Pereira et al., 2018). The review followed recommendations from Preferred Reporting Items for Systematic Reviews and Meta-analysis (Prisma) (Moher et al., 2009). The following databases were examined until November 2020: PubMed, Science Direct, ISI Web of Science and Scopus. The search keywords with the combinations used were "coronavirus", "COVID-19", "SARS-CoV-2" and "clinical characteristics"; using Boolean connectors "And", "Or" and "And Not". Descriptors were defined using the PICOS method (Santos et al., 2007). Participants (P): COVID-19 patients who have the severe form of the disease or who have died; the intervention (I): identification of comorbidities; control groups (C): COVID-19 patients without the severe form of the disease or who have recovered from the disease; outcome (O): presence or absence of comorbidities in the group of patients with non-severe or severe COVID-19 and patients who recovered or have died from COVID-19; Study design (S): a retrospective cohort. The surveys were not limited by the language or country of the primary studies. However, only articles published in English were qualified.

\subsection{Eligibility criteria}

The inclusion criteria to select studies in our meta-analysis were: (1) studies with a retrospective cohort design; (2) studies that assessed the association between comorbidities and severe COVID-19; (3) studies that assessed the association between comorbidities and death in COVID-19 patients. The exclusion criteria were: (1) systematic/integrative/narrative review; (2) letters to editors; (3) case reports; (4) editorials, (5) conference abstracts, and (6) duplicates articles.

\subsection{Evaluation of studies}

Titles, abstracts and full articles were independently assessed by three researchers (ELM, DMS and ACMS). Inconsistencies among the researchers were elucidated by discussion after re-evaluating the article. Three investigators separately assessed the quality of the included studies using the Newcastle-Ottawa Scale (NOS) standards (PHNS, JAS, and MASBJ) (Stang, 2010). The quality of the studies was classified as low quality (score < 4), medium quality (score 4-6) and high quality (score > 7). The authors' evaluation form is summarized in Supplementary 1.

2.4. Data extraction 
The data of interest for each accepted study were extracted into a data extraction form developed specifically for this systematic review. We extracted the following variables: author, year of publication, sex, average age, number of participants, number of patients with comorbidities. Subsequently, they were categorized as patients with severe and non-severe COVID19; patients who died and recovered from COVID-19. Two investigators collected information from each study, and a third investigator independently reviewed the extracted data for completeness and accuracy from the original studies (MLFS, GKMOS, JMF).

\subsection{Statistical analysis}

Review Manager (version 5.3) software was used for statistical analysis, considering Odds Ratio (OR) and an estimate of the $95 \%$ confidence intervals (CIs) for each study and the pooled OR were established by $\mathrm{Z}$ test $(\mathrm{p}<.05)$. The results were calculated to assess the sensitivity. The I2 statistic and Cochran's Q test (Higgins \& Thompson, 2002) were used to assess statistical heterogeneity. We calculated the pooled ORs using fixed-effects model (when P heterogeneity $>0.05$ or I $<50 \%$ ) and random-effects model (when $\mathrm{P}$ heterogeneity $<0.05$ or $\mathrm{I} 2>50 \%$ ). Egger's test was calculated to detect bias in comparisons, using the metafor package (Nicodemus, 2008) in the R Project for Statistical version 3.6.2. (TNR font 10 justified - space 1,5).

\section{Results}

\subsection{Search results}

Searches in the four databases identified a total of 3,228 articles (PubMed: 1283, Scopus: 947, Web of Science: 755, Science Direct: 243). After removing duplicates, 1,546 articles were considered for the studies selection process. From the 1,546 articles, 1,421 were excluded after analysis of titles and abstracts. Thus, 125 full-text articles were carefully reviewed. Applying the inclusion and exclusion criteria, 48 studies were included in the qualitative and quantitative (meta-analysis) synthesis (Figure 1).

The data for all participants included in the meta-analysis (344,290 COVID-19 patients) were divided into subgroups, according to patient characteristics. The first subgroup included studies that analysed non-severe and severe cases of COVID19 (2,501 severe and 6,567 non-severe patients) (Charlotte et al., 2020; Chen et al., 2020a; Dang et al., 2020; de la Rica et al., 2020; Fang et al., 2020; Feng et al., 2020; Guan et al., 2020; He et al., 2020a; He et al., 2020b; Huang et al., 2020; Jiang et al., 2020; Jin et al., 2020; Lee \& Kim, 2020; Li et al., 2020a; Li et al., 2020b; Li et al., 2020c; Liao et al., 2020; Liu et al., 2020a; Liu et al., 2020b; Lv et al., 2020; Shi et al., 2020a; Shu et al., 2020; Wang et al., 2020a; Wang et al., 2020b; Wang et al., 2020c; Wu et al., 2020a; Xie et al., 2020; Yang et al., 2020b; Yao et al., 2020; Zhang et al., 2020a; Zhang et al., 2020b; Zhang et al., 2020c; Zheng et al., 2020a; Zhu et al., 2020).

The second subgroup was composed of studies that evaluated hospitalized COVID-19 patients who recovered or died (39,722 died and 295,500 recovered) (Chen et al., 2020b; Chen et al., 2020c; Chen et al., 2020d; Deng et al., 2020; GuisadoVasco et al., 2020; Hu et al., 2020; Javanian et al., 2020; Li et al., 2020c; Morrison et al., 2020; Namendys-Silva et al., 2020; Parra-Bracamonte et al., 2020; Shang et al., 2020; Vena et al., 2020; Wu et al., 2020; Xie et al., 2020; Yao et al., 2020; Zhou et al., 2020). The characteristics of the studies included in the meta-analysis are shown in Tables $1 \mathrm{~A}$ and $1 \mathrm{~B}$.

\subsection{Meta-analysis}

\subsubsection{Hypertension}

Thirty-four studies (2,501 severe and 6,567 non-severe COVID-19 patients) were included in the meta-analysis to assess susceptibility to severe COVID-19 in hypertensive individuals. The pooled ORs showed that patients with hypertension had a 2.38-fold increased risk of developing the severe form of COVID-19 (OR $=2.38$ [95\% CI $=1.91-2.96]$, P $<0.00001)$ 
(Table 2). The forest plot of this association is shown in Figure 2A. In this analysis, the Egger test confirmed the presence of publication bias (Egger test: $\mathrm{Z}=6.9149, \mathrm{P}<0.0001)$. Furthermore, heterogeneity was detected among the included studies $(\chi 2$ $=86.94, \mathrm{P}<0.00001, \mathrm{I} 2=62 \%)($ Table 2$)$.

Figure 1 - Process of selecting studies for meta-analysis.

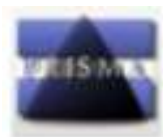

PRISMA 2009 Flow Diagram
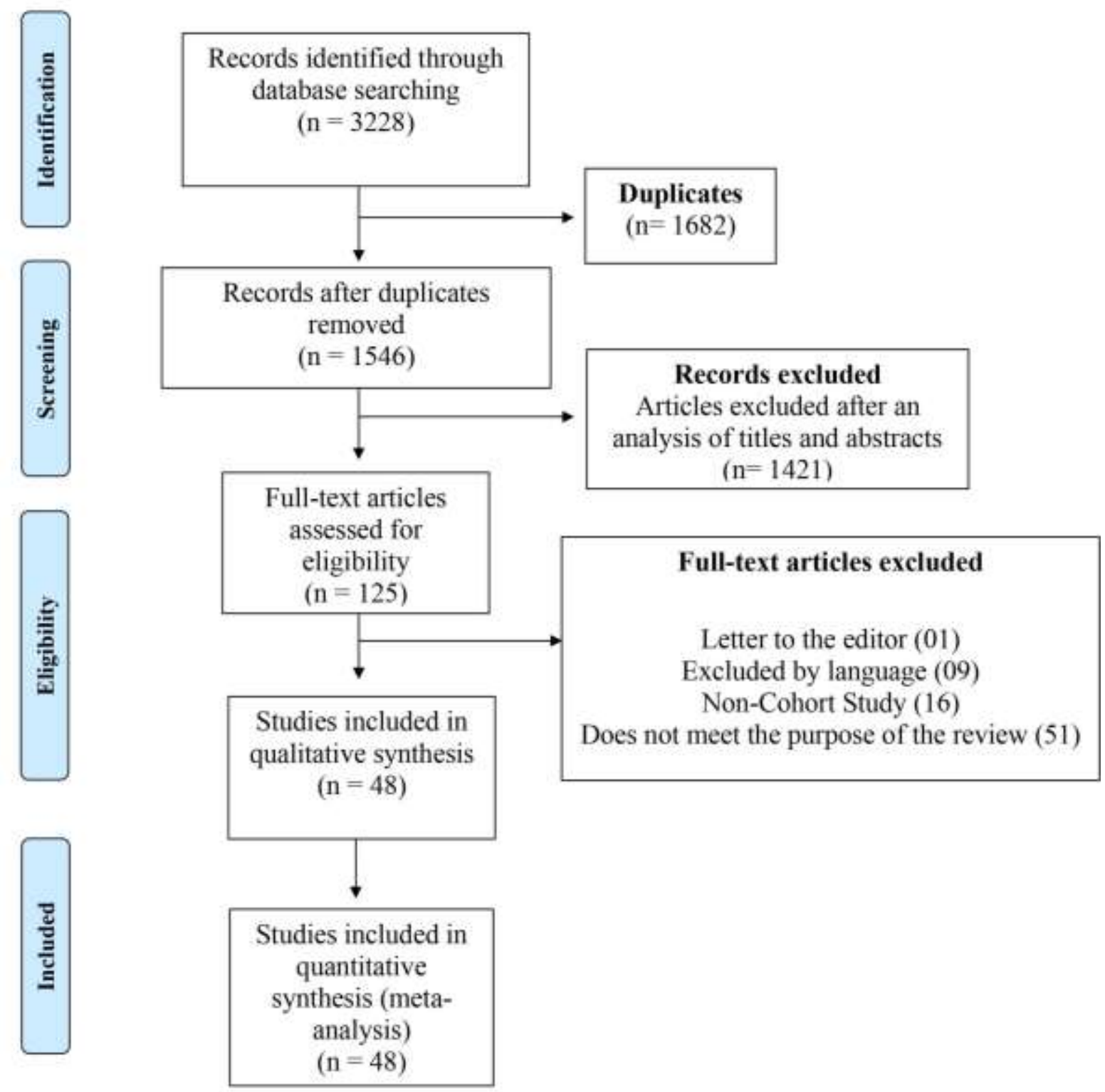

From: Moher D, Liberat A. Tetzlaff J, Altman DG. The PRISMA Group (2009). Preferred Reporting Items for Systematic Reviews and MetaAnalyses: The PRISMA Statement. PLOS Med 6(7): e1000097, doi: 10.1371/joumal pmed 1000097

For more information, visit woww, prisma-statement,org.

Source: author of this research (2020). 
Research, Society and Development, v. 10, n. 2, e50010212533, 2021

(CC BY 4.0) | ISSN 2525-3409 | DOI: http://dx.doi.org/10.33448/rsd-v10i2.12533

Table 1A - Characteristics of the studies included in the meta-analyses.

\begin{tabular}{|c|c|c|c|c|c|c|c|c|c|c|c|c|c|c|}
\hline \multirow[t]{2}{*}{ Author } & \multicolumn{3}{|c|}{ Patients } & \multirow[t]{2}{*}{ Country } & \multirow{2}{*}{$\begin{array}{c}\text { Age } \\
\text { (median) }\end{array}$} & \multirow[t]{2}{*}{ Groups } & \multicolumn{8}{|c|}{ Comorbidities } \\
\hline & All & Female & Male & & & & Hypertension & Diabetes & $\begin{array}{c}\text { Cardiovascular } \\
\text { disease }\end{array}$ & CPD & CKD & $\begin{array}{c}\text { Cerebrovascular } \\
\text { disease }\end{array}$ & CLD & Malignancy \\
\hline Charlotte et al., 2020 & 196 & 77 & 119 & Switzerland & 70 & Without ICU stay vs. With ICU stay & $118(60.2 \%)$ & $52(26.5 \%)$ & $47(24.0 \%)$ & $16(8.2 \%)$ & 0 & 0 & 0 & $15(7.6 \%)$ \\
\hline Chen(1) et al., 2020 & 48 & 11 & 37 & China & 64.4 & Severe/critically vs. Moderate & $23(49.7 \%)$ & $12(25 \%)$ & $8(16.7 \%)$ & $2(4.2 \%)$ & 0 & $6(12.5 \%)$ & $4(8.3 \%)$ & $6(12.5 \%)$ \\
\hline Chen(2) et al., 2020 & 203 & 95 & 108 & China & 54 & Died vs. Survived & $43(21.2 \%)$ & $16(7.9 \%)$ & $16(7.9 \%)$ & $8(3.9 \%)$ & $8(3.9 \%)$ & $9(4.4 \%)$ & $8(3.9 \%)$ & $7(3.4 \%)$ \\
\hline Chen(3) et al., 2020c & 274 & 103 & 171 & China & 62 & Death vs. Recovered & $93(33.9 \%)$ & $47(17.1 \%)$ & $23(8.4 \%)$ & $18(6.6 \%)$ & $4(1.5 \%)$ & $4(1.5 \%)$ & 0 & $7(2.5 \%)$ \\
\hline Chen(4) et al., 2020 & 681 & 319 & 362 & China & 65 & Survivors vs. Non-survivors & $293(43.0 \%)$ & $114(16.7 \%)$ & $80(11.7 \%)$ & $15(2.2 \%)$ & $27(4.0 \%)$ & $33(4.8 \%)$ & 0 & 0 \\
\hline Dang et al., 2020 & 17 & 5 & 12 & China & 88 & Severe vs. Non-severe & $9(52.9 \%)$ & $5(29.4 \%)$ & $8(47.1 \%)$ & $3(17.6 \%)$ & $6(35.3 \%)$ & 0 & 0 & $2(11.8 \%)$ \\
\hline Deng et al., 2020 & 225 & 101 & 124 & China & NP & Death vs. Recovered & $58(25.8 \%)$ & $26(11.6 \%)$ & $17(7.6 \%)$ & $25(11.1 \%)$ & 0 & 0 & 0 & $8(3.6 \%)$ \\
\hline Fang et al., 2020 & 1,280 & 665 & 615 & China & NP & POTC vs. PSTC vs. РCTC & $423(33.0 \%)$ & $184(14.4 \%)$ & $130(10.2 \%)$ & $36(2.8 \%)$ & $20(1.6 \%)$ & $13(1.0 \%)$ & $17(1.3 \%)$ & $13(1.0 \%)$ \\
\hline Feng et al., 2020 & 476 & 205 & 271 & China & 53 & Severe/critically vs. Moderate & $113(23.7 \%)$ & $49(10.3 \%)$ & $38(8 \%)$ & $22(4.6 \%)$ & $4(0.8 \%)$ & $17(3.6 \%)$ & 0 & $12(2.5 \%)$ \\
\hline Guan et al., 2020 & 1,099 & 459 & 640 & China & 47 & Severe vs. Non-severe & $165(15 \%)$ & $81(7.4 \%)$ & $27(2.5 \%)$ & $12(1.1 \%)$ & $8(0.7 \%)$ & $15(1.4 \%)$ & $23(2.1 \%)$ & $10(0.9 \%)$ \\
\hline Guisado-Vasco et al., 2020 & 607 & 212 & 394 & Spain & 69 & Survivors vs. Non-survivors & $276(46.9 \%)$ & $95(16.2 \%)$ & $133(22.6 \%)$ & $114(19.4 \%)$ & $22(3.7 \%)$ & $21(3.6 \%)$ & $24(4.1 \%)$ & $77(13.1 \%)$ \\
\hline He(1) et al., 2020 & 288 & 157 & 131 & China & 48.5 & Severe vs. Non-severe & $84(29.2 \%)$ & $24(8.3 \%)$ & $85(29.5 \%)$ & $5(1.7 \%)$ & $8(2.8 \%)$ & 0 & $10(3.5 \%)$ & $6(2.1 \%)$ \\
\hline He(2) et al., 2020 & 95 & 42 & 53 & China & 57.3 & Common vs. Severe vs. Critical & $33(34.7 \%)$ & $8(8.4 \%)$ & $13(13.7 \%)$ & 0 & 0 & $13(13.7 \%)$ & 0 & 0 \\
\hline Hu et al., 2020 & 105 & 43 & 62 & China & NP & Survivors vs. Non-survivors & $28(26.7 \%)$ & $4(3.8 \%)$ & $6(5.7 \%)$ & $12(11.4 \%)$ & 0 & $4(3.8 \%)$ & 0 & $6(5.7 \%)$ \\
\hline Huang et al., 2020 & 54 & 26 & 28 & China & 41 & Common vs. Severe & $8(14.8 \%)$ & $5(9.3 \%)$ & $8(14.8 \%)$ & $2(3.9 \%)$ & 0 & $3(5.3 \%)$ & $4(7.4 \%)$ & 0 \\
\hline Javanian et al., 2020 & 100 & 49 & 51 & Iran & 60.1 & Deceased patients vs. Survivor patients & $32(32.0 \%)$ & $37(37.0 \%)$ & $20(20.0 \%)$ & $12(12.0 \%)$ & $12(12.0 \%)$ & $3(3.0 \%)$ & $3(3.0 \%)$ & $4(4.0 \%)$ \\
\hline Jiang et al., 2020 & 60 & 25 & 35 & China & 41 & Severe vs. Non-severe & $5(8.3 \%)$ & $1(1.7 \%)$ & 0 & $1(1.7 \%)$ & 0 & 0 & $2(3.3 \%)$ & 0 \\
\hline Jin et al., 2020 & 45 & 27 & 18 & China & 58.8 & Severe to critically vs. Mild to moderate & $17(37.7 \%)$ & $5(11.1 \%)$ & $13(28.8 \%)$ & $3(6.7 \%)$ & $2(4.4 \%)$ & 0 & 0 & $2(4.4 \%)$ \\
\hline Lee and Kim, 2020 & 51 & 29 & 22 & South Korea & 58 & Mild vs. Severe & $14(27.4 \%)$ & $8(15.7 \%)$ & $7(13.7 \%)$ & $4(7.8 \%)$ & $1(2.0 \%)$ & 0 & & $4(7.8 \%)$ \\
\hline Li(1) et al., 2020 & 548 & 269 & 279 & China & 60 & Severe vs. Non-severe & $166(30.3 \%)$ & $83(15.1 \%)$ & $34(6.2 \%)$ & $22(4.0 \%)$ & $10(1.8 \%)$ & 0 & $5(0.9 \%)$ & $24(4.7 \%)$ \\
\hline $\mathrm{Li}(2)$ et al., 2020 & 312 & 125 & 187 & China & 69.2 & Severe vs. Non-severe & $178(57.1 \%)$ & $121(38.8 \%)$ & $93(29.8 \%)$ & $27(8.6 \%)$ & $10(3.2 \%)$ & $20(6.4 \%)$ & $11(3.5 \%)$ & $12(3.8 \%)$ \\
\hline Li(3) et al., 2020 & 523 & 273 & 250 & China & 54.2 & $\begin{array}{l}\text { Non-ICU vs. ICU; ICU Survivors vs. ICU } \\
\text { Non-survivors }\end{array}$ & $130(25.0 \%)$ & $94(18.0 \%)$ & $38(7.3 \%)$ & 0 & 0 & 0 & 0 & 0 \\
\hline Liao et al., 2020 & 148 & 74 & 74 & China & $\mathrm{NP}$ & $\begin{array}{l}\text { Mild or moderate progressed to severe vs. } \\
\text { Match mild or moderate }\end{array}$ & $30(20.3 \%)$ & $7(4.7 \%)$ & $7(4.7 \%)$ & $3(2.0 \%)$ & $1(0.7 \%)$ & $4(2.7 \%)$ & 0 & 0 \\
\hline Liu(1) et al., 2020 & 140 & 91 & 49 & China & 65.5 & Severe vs. Mild & $63(45 \%)$ & $34(24.3 \%)$ & $35(25 \%)$ & 0 & 0 & 0 & 0 & 0 \\
\hline
\end{tabular}

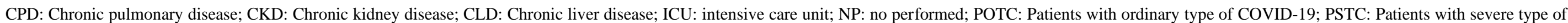
COVID-19; PCTC: Patients with critical type of COVID-19. Source: author of this research, 2020.

Table 1B - Characteristics of the studies included in the meta-analyses. 
Research, Society and Development, v. 10, n. 2, e50010212533, 2021

(CC BY 4.0) | ISSN 2525-3409 | DOI: http://dx.doi.org/10.33448/rsd-v10i2.12533

\begin{tabular}{|c|c|c|c|c|c|c|c|c|c|c|c|c|c|c|}
\hline \multirow[t]{2}{*}{ Author } & \multicolumn{3}{|c|}{ Patients } & \multirow[t]{2}{*}{ Country } & \multirow{2}{*}{$\begin{array}{c}\text { Age } \\
\text { (median) }\end{array}$} & \multirow[t]{2}{*}{ Groups } & \multicolumn{8}{|c|}{ Comorbidities } \\
\hline & All & Female & Male & & & & Hypertension & Diabetes & $\begin{array}{c}\text { Cardiovascular } \\
\text { disease }\end{array}$ & CPD & CKD & $\begin{array}{c}\text { Cerebrovascular } \\
\text { disease }\end{array}$ & CLD & Malignancy \\
\hline Liu(2) et al., 2020 & 72 & 33 & 39 & China & 46.2 & $\begin{array}{l}\text { Uncomplicated Illness vs. Mild vs. } \\
\text { Severe }\end{array}$ & $7(9.7 \%)$ & $2(2.8 \%)$ & $7(9.7 \%)$ & 0 & $1(1.4 \%)$ & 0 & 0 & 0 \\
\hline Lv et al., 2020 & 354 & 179 & 175 & China & 62 & Mild vs. Severe & $74(20.9 \%)$ & $35(9.9 \%)$ & $18(5.1 \%)$ & $6(1.7 \%)$ & 0 & 0 & 0 & $2(0.6 \%)$ \\
\hline Morrison et al. 2020 & 81 & 25 & 56 & EUA & 64 & Survivors vs. Non-survivors & $60(74.1 \%)$ & $37(45.7 \%)$ & $23(28.4 \%)$ & $15(18.5 \%)$ & $1(1.2 \%)$ & 0 & 0 & 0 \\
\hline $\begin{array}{l}\text { Namendys-Silva et al., } \\
2020\end{array}$ & 164 & 50 & 114 & Mexico & 57.3 & Alive vs. Dead & $63(38.4 \%)$ & $53(32.3 \%)$ & 0 & $4(2.4 \%)$ & $6(3.6 \%)$ & 0 & 0 & $10(6.0 \%)$ \\
\hline $\begin{array}{l}\text { Parra-Bracamonte et } \\
\text { al., } 2020\end{array}$ & 331,298 & 153,143 & 178,155 & Mexico & 44 & Survivors vs. Non-survivors & $66,170(20 \%)$ & $53,712(16.2 \%)$ & $7,351(2.2 \%)$ & $14,441(4.4 \%)$ & $6,895(2.1 \%)$ & 0 & 0 & 0 \\
\hline Rica et al., 2020 & 48 & 16 & 32 & Spain & 66 & Non-ICU vs. ICU & $33(70.2 \%)$ & $11(24.4 \%)$ & $14(29.8 \%)$ & $5(10.6 \%)$ & $8(17.4 \%)$ & 0 & 0 & $10(21.3 \%)$ \\
\hline Shang et al., 2020 & 113 & 40 & 73 & China & 66 & Survivors vs. Non-survivors & $50(44.2 \%)$ & $20(17.7 \%)$ & $28(24.8 \%)$ & $5(4.4 \%)$ & $9(8.0 \%)$ & 0 & $8(7.1 \%)$ & $8(7.1 \%)$ \\
\hline Shi et al., 2020 & 134 & 69 & 65 & China & 46 & Severe vs. Non-severe & $20(14.9 \%)$ & $9(6.7 \%)$ & $6(4.5 \%)$ & 0 & 0 & $6(4.5 \%)$ & $5(3.7 \%)$ & $5(3.7 \%)$ \\
\hline Shu et al., 2020 & 571 & 293 & 278 & China & 50 & Transferred patients vs. Stable patients & $55(9.6 \%)$ & $17(3.0 \%)$ & $12(2.1 \%)$ & 0 & $1(0.2 \%)$ & 0 & 0 & 0 \\
\hline Vena et al., 2020 & 317 & 104 & 213 & Italy & 71 & $\begin{array}{l}\text { In-hospital survivors vs. In-hospital } \\
\text { non-survivors }\end{array}$ & $149(47 \%)$ & $49(15.5 \%)$ & $63(19.9 \%)$ & $18(5.7 \%)$ & $22(6.9 \%)$ & 0 & 0 & $23(7.2 \%)$ \\
\hline Wang(1) et al., 2020 & 138 & 63 & 75 & China & 56 & ICU vs. Non-ICU & $43(31.2 \%)$ & $14(10.1 \%)$ & $20(14.5 \%)$ & $4(2.9 \%)$ & $4(2.9 \%)$ & $7(5.1 \%)$ & $4(2.9 \%)$ & $10(7.2 \%)$ \\
\hline Wang(2) et al., 2020 & 1,012 & 488 & 524 & China & 50 & $\begin{array}{l}\text { Patients with aggravation of illness } \\
\text { during follow up vs. Patients without } \\
\text { aggravation of illness during follow up }\end{array}$ & $46(4.5 \%)$ & $27(2.7 \%)$ & $15(1.5 \%)$ & 0 & 0 & 0 & 0 & 0 \\
\hline Wang(3) et al., 2020 & 209 & 104 & 105 & China & NP & Severe vs. Non-severe & $27(12.9 \%)$ & $11(5.3 \%)$ & $5(2.4 \%)$ & 0 & 0 & $6(2.9 \%)$ & 0 & 0 \\
\hline Wu et al., 2020 & 201 & 73 & 128 & China & 51 & $\begin{array}{l}\text { With ARDS vs. Without ARDS Died } \\
\text { vs. Alive }\end{array}$ & $39(19.4 \%)$ & $22(10.9)$ & $8(4.0 \%)$ & $5(2.5 \%)$ & $2(1.0 \%)$ & 0 & $7(3.5 \%)$ & $1(0.5 \%)$ \\
\hline Xie(1) et al., 2020 & 79 & 35 & 44 & China & 60 & Severe vs. Moderate & $14(17.7 \%)$ & $8(10.1 \%)$ & $7(8.9 \%)$ & 0 & 0 & 0 & 0 & 0 \\
\hline Xie(2) et al., 2020 & 733 & 256 & 477 & China & 65 & Survivors vs. Non-survivors & $308(42 \%)$ & $138(18.8 \%)$ & $108(14.7 \%)$ & $37(5.0 \%)$ & $13(1.8 \%)$ & $34(4.6 \%)$ & $11(1.5 \%)$ & $24(3.3 \%)$ \\
\hline Yang et al., 2020 & 136 & 70 & 66 & China & 56 & Moderate vs. Severe and Critical & $36(27.1 \%)$ & $20(14.7 \%)$ & $9(6.6 \%)$ & 0 & $4(2.9 \%)$ & $1(0.7 \%)$ & $8(5.9 \%)$ & $4(2.9 \%)$ \\
\hline Yao et al., 2020 & 108 & 65 & 43 & China & NP & $\begin{array}{l}\text { Severe vs. Non-severe Severe- } \\
\text { alive vs. Severe-dead }\end{array}$ & $16(14.8 \%)$ & $5(4.6 \%)$ & $4(3.7 \%)$ & $3(2.8 \%)$ & 0 & 0 & $2(1.9 \%)$ & $2(1.9 \%)$ \\
\hline Zhang(1) et al., 2020 & 140 & 69 & 71 & China & 57 & Severe vs. Non-severe & $42(30.0 \%)$ & $17(12.1 \%)$ & $7(5.0 \%)$ & $2(1.4 \%)$ & $2(1.4 \%)$ & 0 & $8(5.7 \%)$ & 0 \\
\hline Zhang(2) et al., 2020 & 111 & 65 & 46 & China & 38 & Deterioration vs. Discharge & $15(13.5 \%)$ & $14(12.6 \%)$ & $3(2.7 \%)$ & $3(2.7 \%)$ & 0 & 0 & $1(0.9 \%)$ & $8(7.2 \%)$ \\
\hline Zhang(3) et al., 2020 & 88 & 43 & 45 & China & 55 & Moderate vs. Severe vs. Critical & $23(26.1 \%)$ & $11(12.5 \%)$ & $8(9.1 \%)$ & 0 & $4(4.5 \%)$ & $5(5.7 \%)$ & 0 & $3(3.4 \%)$ \\
\hline Zheng et al., 2020 & 161 & 81 & 80 & China & 45 & Severe vs. Non-severe & $22(13.7 \%)$ & $7(4.3 \%)$ & $4(2.5 \%)$ & $6(3.7 \%)$ & 0 & $4(2.5 \%)$ & $4(2.5 \%)$ & 0 \\
\hline Zhou et al., 2020 & 191 & 72 & 119 & China & 56 & Survivor vs. Non-survivor & $58(30.4 \%)$ & $36(18.8 \%)$ & $15(7.8 \%)$ & $6(3.1 \%)$ & $2(1.0 \%)$ & 0 & 0 & $2(1.0 \%)$ \\
\hline Zhu et al., 2020 & 127 & 82 & 45 & China & 50.9 & Severe vs. Non-severe & $31(24.4 \%)$ & $10(7.9 \%)$ & $6(4.7 \%)$ & $6(4.7 \%)$ & 0 & 0 & $7(5.5 \%)$ & $5(3.9 \%)$ \\
\hline
\end{tabular}

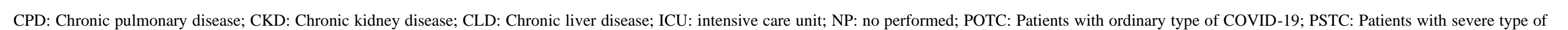
COVID-19; PCTC: Patients with critical type of COVID-19. Source: author of this research, 2020. 
Seventeen studies involving 39,722 hospitalized COVID-19 patients who died and 295,500 hospitalized COVID-19 patients who recovered were included in the meta-analysis to assess the risk of death in hypertensive individuals. The pooled ORs showed that hypertensive patients hospitalized for COVID-19 had a 2.43-fold increased risk of dying (OR $=2.43$ [95\% CI $=1.90-3.11], \mathrm{P}<0.00001)$ (Table 2). The forest plot of this association is shown in Figure 3C. In this analysis, publication bias (Egger test: $\mathrm{Z}=46.2239, \mathrm{P}>0.0001)$ and heterogeneity $(\chi 2=70.76, \mathrm{P}<0.00001, \mathrm{I} 2=77 \%$ ) were found (Table 2 ).

Table 2 - Meta-analysis of association between comorbidities and severity/mortality COVID-19.

\begin{tabular}{|c|c|c|c|c|c|c|c|c|c|}
\hline \multirow{2}{*}{ Comorbidity } & \multicolumn{3}{|c|}{ Teste of association } & \multirow{2}{*}{ Model } & \multicolumn{3}{|c|}{ Teste of heterogeneity } & \multicolumn{2}{|c|}{ Egger test } \\
\hline & OR $(95 \% \mathrm{CI})$ & $\mathrm{Z}$ & $p$-value & & $x^{2}$ & $p$-value & $\mathrm{I}^{2}(\%)$ & $\mathrm{Z}$ & $\mathrm{P}$ \\
\hline \multicolumn{10}{|l|}{ Severity } \\
\hline Diabetes & 2.08(1.67-2.60) & 6.52 & $<0.00001$ & $\mathrm{R}$ & 54.21 & 0.01 & 39 & 5.1688 & $<0.0001$ \\
\hline Cardiovascular disease & $2.36(1.98-2.80)$ & 9.77 & $<0.00001$ & $\mathrm{~F}$ & 41.93 & 0.09 & 26 & 3.3947 & 0.0007 \\
\hline Chronic kidney disease & 2.55(1.11-5.84) & 2.21 & 0.03 & $\mathrm{R}$ & 52.45 & $<0.00001$ & 69 & 0.6908 & 0.4897 \\
\hline $\begin{array}{l}\text { Cerebrovascular } \\
\text { disease }\end{array}$ & 2.51(1.68-3.76) & 4.48 & $<0.00001$ & $\mathrm{~F}$ & 10.76 & 0.55 & 0 & 0.1614 & 0.8718 \\
\hline Chronic liver disease & $0.99(0.64-1.52)$ & 0.06 & 0.95 & $\mathrm{~F}$ & 13.28 & 0.58 & 0 & 0.3035 & 0.7615 \\
\hline Malignancy & $1.40(1.00-1.96)$ & 1.94 & 0.05 & $\mathrm{~F}$ & 23.51 & 0.22 & 19 & 0.1432 & 0.8861 \\
\hline Diabetes & $1.93(1.35-2.76)$ & 3.62 & 0.0003 & $\mathrm{R}$ & 104.44 & $<0.00001$ & 85 & 36.2858 & $<0.0001$ \\
\hline Cardiovascular disease & $2.91(2.26-3.73)$ & 8.38 & $<0.00001$ & $\mathrm{R}$ & 30.39 & 0.01 & 51 & 10.4782 & $<0.0001$ \\
\hline $\begin{array}{l}\text { Chronic pulmonary } \\
\text { disease }\end{array}$ & $1.97(1.43-2.72)$ & 4.15 & $<0.0001$ & $\mathrm{R}$ & 23.19 & 0.04 & 44 & 13.3344 & $<0.0001$ \\
\hline Chronic kidney disease & 3.01(1.94-4.66) & 4.94 & $<0.00001$ & $\mathrm{R}$ & 20.05 & 0.04 & 45 & 13.0460 & $<0.0001$ \\
\hline $\begin{array}{l}\text { Cerebrovascular } \\
\text { disease }\end{array}$ & $2.40(1.60-3.60)$ & 4.24 & $<0.0001$ & $\mathrm{~F}$ & 11.15 & 0.08 & 46 & 0.6710 & 0.5022 \\
\hline Chronic liver disease & $1.72(0.87-3.39)$ & 1.56 & 0.12 & $\mathrm{~F}$ & 3.02 & 0.55 & 0 & 0.3098 & 0.7567 \\
\hline Malignancy & $1.81(1.30-2.52)$ & 3.52 & 0.0004 & $\mathrm{~F}$ & 11.29 & 0.42 & 3 & 0.6944 & 0.4874 \\
\hline
\end{tabular}

OR: odds ratio; CI: confidence interval. Source: author of this research (2020).

\subsubsection{Diabetes}

Thirty-four studies containing 2,501 severe and 6,567 non-severe COVID-19 patients were included in the metaanalysis to assess the susceptibility to severe form of the disease. The pooled ORs showed that diabetic patients were associated with a 2.08-fold increased risk of developing the severe COVID-19 (OR = 2.08 [95\% CI = 1.67 - 2.60], P < 0.00001) (Table 2). The forest plot of this association is shown in Figure 2B. In this analysis, publication bias (Egger test: $\mathrm{Z}=$ 5.1688, $\mathrm{P}<0.0001)$ and heterogeneity $(\chi 2=54.21, \mathrm{P}=0.01, \mathrm{I} 2=39 \%)$ were detected (Table 2$)$.

Seventeen studies were included in the meta-analysis to assess the risk of dying from COVID-19 in diabetics. Overall, 39,722 hospitalized COVID-19 patients who died and 295,500 hospitalized COVID-19 patients who recovered were analysed. The pooled ORs showed that COVID-19 patients with diabetes presented a 1.93-fold increased risk of dying (OR = 1.93 [95\% $\mathrm{CI}=1.35-2.76], \mathrm{P}=0.0003$ ) during hospitalization (Table 2). The forest plot of this association is shown in Figure 3D. In this analysis, publication bias (Egger test: $\mathrm{Z}=36.2858, \mathrm{P}<0.0001)$ and heterogeneity $(\chi 2=104.44, \mathrm{P}<0.00001, \mathrm{I} 2=85 \%)$ were found (Table 2). 
The pooled ORs showed that patients with chronic pulmonary disease had a 2.31-fold increased risk of developing the severe form of COVID-19 (OR = 2.31 [95\% CI = $1.72-3.11], \mathrm{P}<0.00001)$ (Table 2). The forest plot of this association is shown in Figure 2D. Publication bias (Egger test: $\mathrm{Z}=0.8841, \mathrm{P}=0.3766)$ and heterogeneity $(\chi 2=19.18, \mathrm{P}=0.57, \mathrm{I} 2=0 \%)$ were not observed in this analysis (Table 2).

Fifteen studies comprising 39,583 hospitalized COVID-19 patients who died 295,344 hospitalized COVID-19 patients who recovered were included in the meta-analysis to assess the risk of death in individuals with chronic pulmonary disease. The pooled ORs showed that COVID-19 patients with chronic pulmonary disease were associated with a 1.97-fold increased risk of dying $(\mathrm{OR}=1.97$ [95\% CI $=1.43-2.72], \mathrm{P}<0.0001)$ during hospitalization (Table 2). The forest plot of this association is shown in Figure 4B. Publication bias (Egger test: $\mathrm{Z}=13.3344, \mathrm{P}<0.0001)$ and heterogeneity $(\chi 2=23.19, \mathrm{P}=$ $0.04, \mathrm{I} 2=44 \%)($ Table 2$)$ were detected.

Figure 3 - The Floret plots of comorbidities associated with severity and mortality by COVID-19.

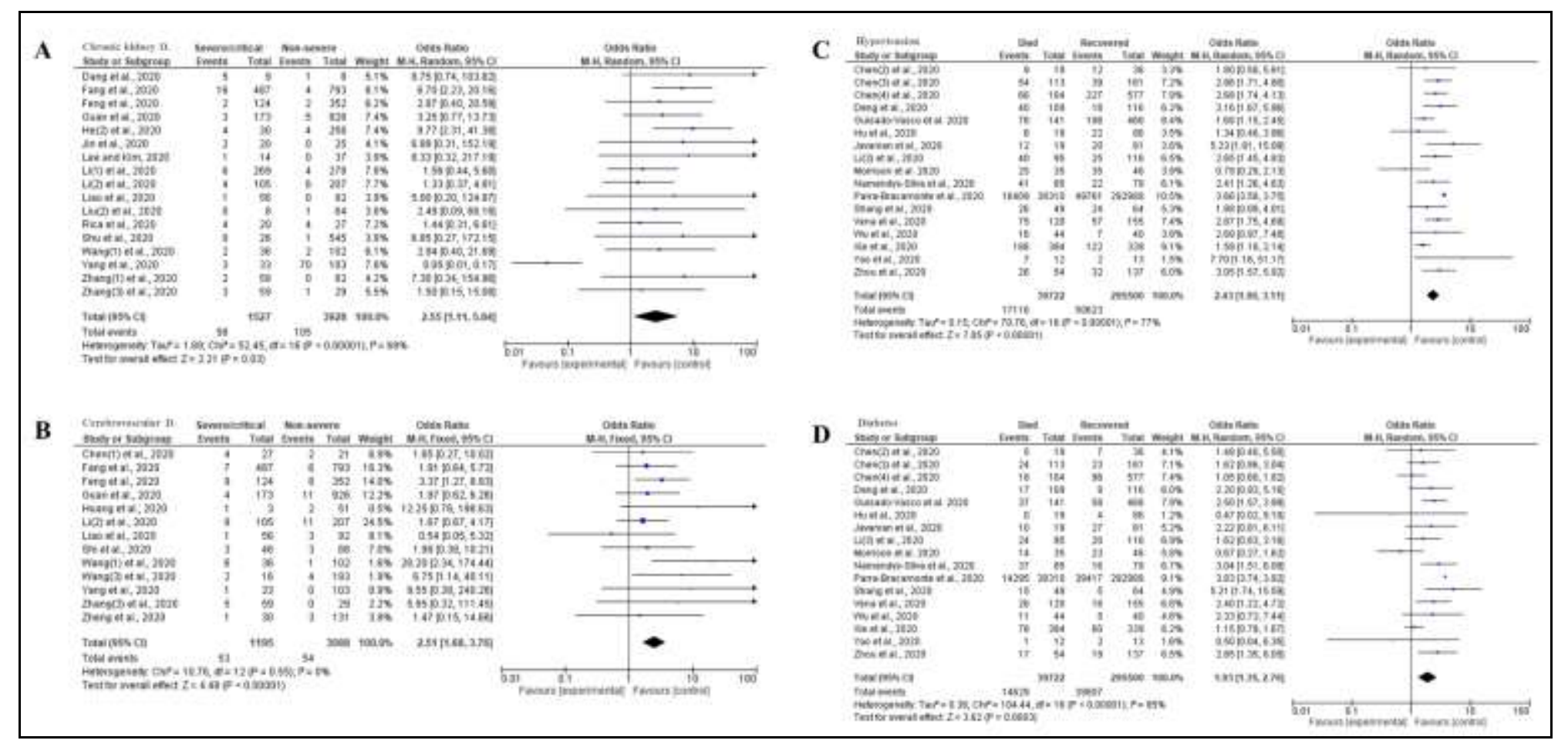

(A) Floret plot of association between Chronic kidney disease and the risk of severe COVID-19. (B) Floret plot of association between Cerebrovascular disease and the risk of severe COVID-19. (C) Floret plot of association between Hypertension and the risk of COVID-19 death. (D) Floret plot of association between Diabetes and the risk of COVID-19 death. Source: author of this research (2020).

\subsubsection{Chronic kidney disease}

Seventeen studies containing 1,527 severe and 3,928 non-severe COVID-19 patients were included in the metaanalysis to assess susceptibility to severe form of the disease in individuals with chronic kidney disease. The pooled ORs showed that patients with chronic kidney disease had a 2.55-fold increased risk of developing severe COVID-19 (OR $=2.55$ [95\% CI $=1.11-5.84], \mathrm{P}=0.03$ ) (Table 2). The forest plot of this association is shown in Figure 3A. No publication of bias (Egger test: $\mathrm{Z}=0.6908, \mathrm{P}=0.4897$ ) was found, but heterogeneity $(\chi 2=52.45, \mathrm{P}<0.00001, \mathrm{I} 2=69 \%)$ was observed in this analysis (Table 2).

Twelve studies comprising 39,443 hospitalized COVID-19 patients who died and 295,129 hospitalized COVID-19 patients who recovered were included in the meta-analysis to assess the risk of death in individuals with chronic kidney disease. The pooled ORs showed that hospitalized COVID-19 patients with chronic kidney disease had a 3.01- fold increased 
risk of dying $(\mathrm{OR}=3.01$ [95\% CI = 1.94 - 4.66], $\mathrm{P}<0.00001)$ (Table 2). The forest plot of this association is shown in Figure 4C. Publication of bias (Egger test: $\mathrm{Z}=13.0460, \mathrm{P}<0.0001)$ and heterogeneity $(\chi 2=20.05, \mathrm{P}=0.04, \mathrm{I} 2=45 \%)$ were detected in this analysis (Table 2).

Figure 4 - The Floret plots of comorbidities associated with COVID-19 mortality.

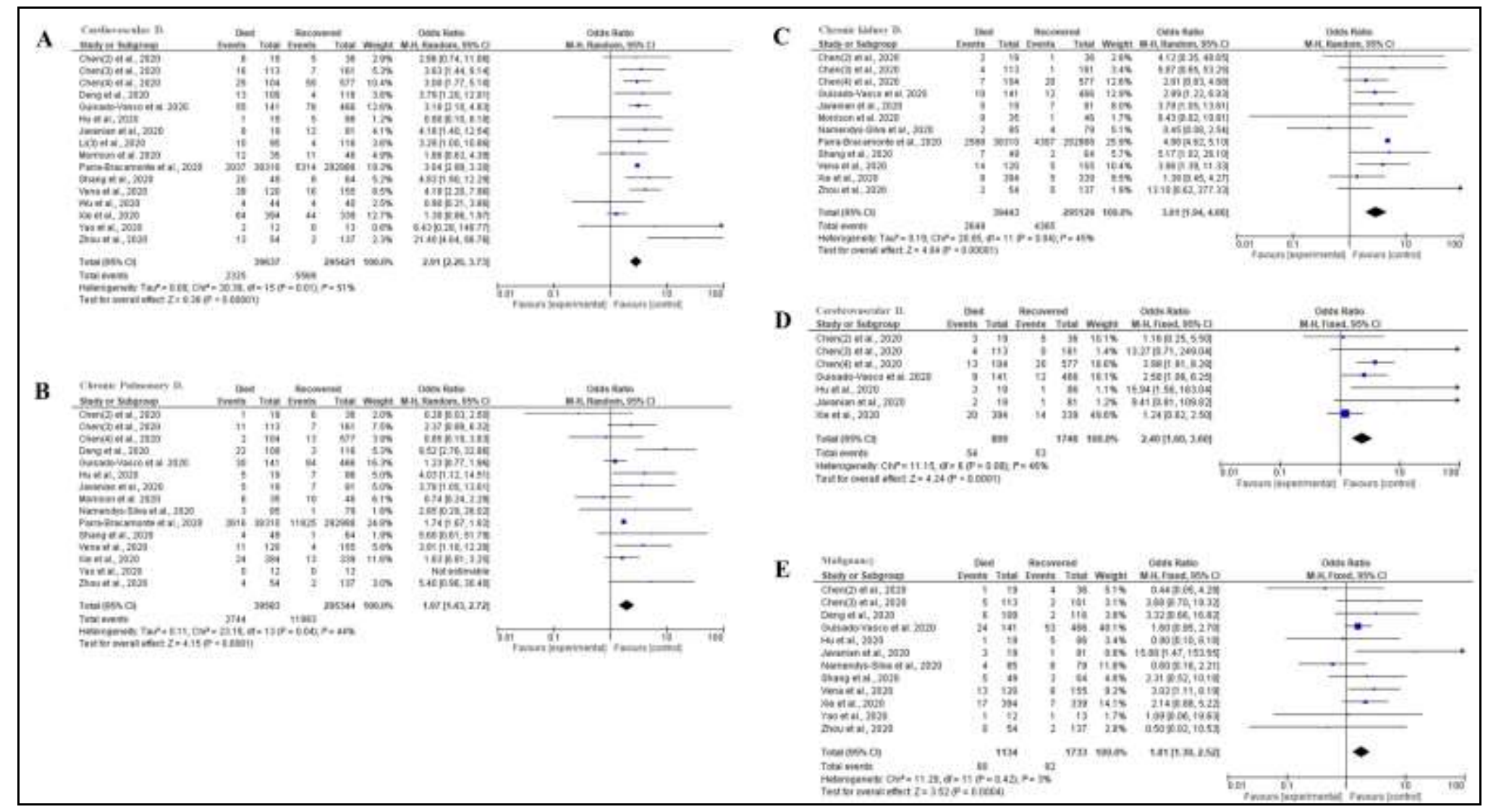

(A) Floret plot of association between Cardiovascular disease and the risk of COVID-19 death. (B) Floret plot of association between Chronic pulmonary disease and the risk of COVID-19 death. (C) Floret plot of association between Chronic kidney disease and the risk of COVID-19 death. (D) Floret plot of association between Cerebrovascular disease and the risk of COVID-19 death. (E) Floret plot of association between Malignancy and the risk of COVID-19 death. Source: author of this research (2020).

\subsubsection{Cerebrovascular disease}

Thirteen studies were included in the meta-analysis to assess susceptibility to severe COVID-19 in individuals with cerebrovascular disease. The sample was composed of 1,195 severe and 3,088 non-severe COVID-19 patients. The pooled ORs showed that patients with cerebrovascular disease were associated with a 2.51 -fold increased risk of developing the severe COVID-19 (OR $=2.51$ [95\% CI = $1.68-3.76], \mathrm{P}<0.00001)$ (Table 2). The forest plot of this association is shown in Figure 3B. Publication of bias (Egger test: $\mathrm{Z}=0.1614, \mathrm{P}=0.8718)$ and heterogeneity $(\chi 2=10.76, \mathrm{P}=0.55, \mathrm{I} 2=0 \%)$ were not found in this analysis (Table 2).

Seven studies containing 809 hospitalized COVID-19 patients who died and 1,746 hospitalized COVID-19 patients who recovered were included in the meta-analysis to assess the risk of death in individuals with cerebrovascular disease. The pooled ORs showed that hospitalized COVID-19 patients with cerebrovascular disease had a 2.40-fold increased risk of death $(\mathrm{OR}=2.40[95 \% \mathrm{CI}=1.60-3.60], \mathrm{P}<0.0001)$ (Table 2). The forest plot of this association is shown in Figure 4D. Publication bias (Egger test: $\mathrm{Z}=0.6710, \mathrm{P}=0.5022)$ and heterogeneity $(\chi 2=11.15, \mathrm{P}=0.08, \mathrm{I} 2=46 \%)$ were not observed in this analysis (Table 2). 


\subsubsection{Chronic liver disease}

Sixteen studies were included in the meta-analysis to assess susceptibility to severe COVID-19 in individuals with the chronic liver disease. These studies analysed 1,364 severe and 3,380 non-severe COVID-19 patients. There was no significant association between patients with the chronic liver disease and severe form of COVID-19 (OR $=0.99$ [95\% CI $=0.64-1.52$ ], $\mathrm{P}=0.95$ ) (Table 2). Publication of bias (Egger test: $\mathrm{Z}=0.3035, \mathrm{P}=0.7615)$ and heterogeneity $(\chi 2=13.28, \mathrm{P}=0.58, \mathrm{I} 2=0 \%)$ were not observed in this analysis (Table 2).

Five studies containing 240 hospitalized COVID-19 patients who died and 660 hospitalized COVID-19 patients who recovered were included in the meta-analysis to assess the risk of death in individuals with chronic liver disease. There was no significant association between patients with chronic liver disease and the risk of death for COVID-19 $(\mathrm{OR}=1.72$ [95\% CI = 0.87 - 3.39], $\mathrm{P}=0.14$ ) (Table 2). Publication of bias (Egger test: $\mathrm{Z}=0.3098, \mathrm{P}=0.7567)$ and heterogeneity $(\chi 2=3.02, \mathrm{P}=$ $0.55, \mathrm{I} 2=0 \%$ ) were not detected in this analysis (Table 2 ).

\subsubsection{Malignancy}

Twenty studies with 1,787 severe and 3,781 non-severe COVID-19 patients were included in the meta-analysis to assess susceptibility to severe COVID-19 in individuals with some type of cancer. No association was found between malignancy and severe form of COVID-19 (OR $=1.40$ [95\% CI $=1.00-1.96], \mathrm{P}=0.05$ ) (Table 2). Publication of bias (Egger test: $\mathrm{Z}=0.1432, \mathrm{P}=0.8861)$ and heterogeneity $(\chi 2=23.51, \mathrm{P}=0.22, \mathrm{I} 2=19 \%)$ were not detected in this analysis (Table 2$)$.

Twelve studies containing 1,134 hospitalized COVID-19 patients who died and 1,733 hospitalized COVID-19 patients who recovered were included in the meta-analysis to assess the risk of death in individuals with malignancy. The pooled ORs showed that COVID-19 patients with malignancy had a 1.81-fold increased risk of death $(\mathrm{OR}=1.81$ [95\% CI = 1.30 - 2.52], $\mathrm{P}=0.0004$ ) during hospitalization (Table 2). The forest plot of this association is shown in Figure 4E. Publication of bias (Egger test: $\mathrm{Z}=0.6944, \mathrm{P}=0.4874)$ and heterogeneity $(\chi 2=11.29, \mathrm{P}=0.42, \mathrm{I} 2=3 \%$ ) were not found in the analysis (Table 2). (TNR font 10 - justified - space 1,5).

\section{Discussion}

Currently, COVID-19 is the most important public health problem in the world, due to its capacity for global expansion. A major challenge for health authorities is to discover the main factors involved in the development of the severe form of the disease and risk of death. Studies have demonstrated a high prevalence of comorbidities in COVID-19 patients who progressed to the severe form of the disease and/or died. We investigated the impact of comorbidities in the susceptibility to severe COVID-19 and the risk of death through a systematic review with meta-analysis.

In our meta-analysis, patients with COVID-19 and with pre-existing cardiovascular disease were about 2-fold more likely to develop severe disease, and among hospitalized COVID-19 patients the risk of death was approximately 3-fold higher in cardiopathy patients when compared to patients without cardiovascular disease. Six recent meta-analyses have shown that COVID-19 patients with cardiovascular disease have approximately a 3- to 4-fold increased risk from developing severe COVID-19 (Aggarwal et al., 2020; Jain \& Yuan, 2020; Liu et al., 2020c; Wang et al., 2020d; Wang et al., 2020e; Yang et al., 2020a). At the same time, the meta-analyses carried out by Tian et al. (2020) and Li et al. (2020) showed that patients with this comorbidity had a risk of death 3.80 and 4.85-fold higher in SARS-CoV-2 infection, respectively (Li et al., 2020e; Tian et al., 2020b). Thus, patients with pre-existing cardiovascular diseases infected with SARS-CoV-2 should be monitored more carefully by healthcare professionals, especially cardiologists, to obtain better clinical management.

Hypertension has been considered an important risk factor for severe COVID-19 and disease fatality (Deng et al., 2020; Zhu et al., 2020). In our meta-analysis, hypertensive patients infected with SARS-COV-2 were about 2-fold more likely to develop severe COVID-19 and/or death from this illness. Six previous meta-analysis revealed an association between 
hypertensive patients and an increased risk of developing severe COVID-19, with an estimated risk of about 2- to 3-fold higher compared to non-hypertensive patients (Jain \& Yuan, 2020; Liu et al., 2020c; Wang et al., 2020d; Wang et al., 2020e; Yang et al., 2020a; Zhang et al., 2020d). Additionally, three recent meta-analyses showed that hypertensive patients with COVID-19 also had a 2- to 3-fold increased risk of dying (Li et al., 2020e; Tian et al., 2020b; Zheng et al., 2020c).

Studies have reported diabetes as a risk factor for worse clinical outcome in patients with COVID-19 (Wang et al., 2020e; Wu et al., 2020b). Our meta-analysis showed that diabetic patients had nearly a 2-fold increased risk of developing the severe form and/or die of COVID-19. Corroborating with our finding, four previous meta-analyses identified that diabetic patients had about a 2.5-fold increased risk of developing the severe form of the disease (Liu et al., 2020c; Wang et al., 2020d; Wang et al., 2020e; Wu et al., 2020b). On the other hand, two meta-analyses found no association between diabetes and severe COVID-19 (Jain \& Yuan, 2020; Yang et al., 2020a). Regarding the risk of mortality, similar results were observed in the metaanalyses conducted by $\mathrm{Wu}$ et al. (2020) and Tian et al. (2020), in which diabetic patients were associated with a 3- and 2-fold higher risk of mortality from COVID-19, respectively (Tian et al., 2020b; Wu et al., 2020b). In addition, a meta-analysis carried out by Zheng et al. (2020) revealed that diabetes was associated with a 3.68-fold higher risk of developing the critical form of COVID-19 or death from the disease (Zheng et al., 2020c). According to Yang et al. (2006), during the SARS infection, fasting plasma glucose levels were negatively associated with arterial oxygenation ( $\mathrm{SaO} 2)$ and this condition was correlated with mortality and hypoxia (Yang et al., 2006d). Thus, diabetic patients are more susceptible to COVID-19, but this effect has not been fully elucidated yet.

Recent studies have reported that patients with pre-existing chronic pulmonary disease have a high risk of complications and worsening lung injury during the pathogenesis of COVID-19 (Daccord et al., 2020; Taghavi-Farahabadi et al., 2020). The clinical characteristics of COVID-19 demonstrated by some studies revealed that the majority of patients with pre-existing chronic pulmonary disease presented respiratory failure and require ICU intervention. Therefore, these patients appear to be the most susceptible to the development of severe COVID-19. We assessed the risk of severity and mortality in patients with chronic pulmonary disease, which included COPD and asthma. We observed that patients with chronic pulmonary disease had nearly a 2-fold increased risk of developing severe form and/or die of COVID-19. A previous metaanalysis revealed that patients with the chronic pulmonary disease also had nearly a 4-fold higher risk of developing the severe form of COVID-19 (Liu et al., 2020c). In addition, two recent meta-analyses showed that COPD patients had approximately a 6-fold increased risk of developing severe COVID-19 (Jain \& Yuan, 2020; Wang et al., 2020d). Regarding the risk of death, Zhao et al. (2020) found that the risk of death from COVID-19 was almost 2-fold higher in patients with COPD (Zhao et al., 2020), similar result to our findings. However, this association was not observed in the meta-analysis by Tian et al. (2020) (Tian et al., 2020b).

Despite a few previous reports, chronic kidney disease has been associated with the severe form of COVID-19 (Adapa et al., 2020). We showed that patients with chronic kidney disease had a 2.55-fold increased risk to develop severe COVID-19. While, hospitalized COVID-19 patients with chronic kidney disease had a 3-fold increased risk of death when compared to patients without chronic kidney disease. Corroborating with our results, Wang et al. (2020) identified that patients with chronic kidney disease were associated with a 2.22-fold increased risk of developing severe COVID-19 (Wang et al., 2020e). Additionally, the meta-analysis conducted by Tian et al. (2020) revealed that patients with chronic kidney disease had a 9.40fold higher risk of death from COVID-19 (Tian et al., 2020b). In contrast, a previous meta-analysis found no association between chronic kidney disease and severe COVID-19, but the small number of studies (4 studies) and patients ( $\mathrm{n}=15$ ) included may have influenced this analysis (Wang et al., 2020d). Several mechanisms can be responsible for the susceptibility of patients with chronic kidney diseases to SARS-CoV-2 infection. First, ACE2 is highly expressed in renal tubular cells, and thus SARS-CoV-2 may directly affect this organ (Fan et al., 2020). Second, that studies have detected kidney injuries in 
COVID-19 patients (Li et al., 2020f). Third, chronic kidney disease leads to a series of complications, such as high blood pressure, anemia, water retention and these complications may have a greater effect on SARS-CoV-2 infection (Babitt \& Lin, 2012; Drawz et al., 2016). Fourth, chronic kidney disease has been linked to uncontrolled chronic inflammation that can affect the immune response during SARS-CoV-2 infection (Imig \& Ryan, 2013; Raj et al., 2015).

Previous reports have suggested that cerebrovascular diseases may lead to a poor outcome in COVID-19 patients (Pranata et al., 2020). In our meta-analysis, patients with cerebrovascular diseases had a 2.51 -fold increased risk to developing severe COVID-19. Among hospitalized COVID-19 patients with cerebrovascular disease the risk of death was 2.82-fold higher when compared to hospitalized COVID-19 patients without cerebrovascular disease. The meta-analysis conducted by Wang et al. (2020) revealed that cerebrovascular disease was associated with a 3.89-fold higher risk of developing severe COVID-19 (Wang et al., 2020d). In relation to the risk of death, Tian et al. (2020) and Pranata et al. (2020) showed that COVID-19 patients with cerebrovascular disease had an increased risk of death (Pranata et al., 2020; Tian et al., 2020b). The pathophysiological mechanism that explains the poor clinical evolution of COVID-19 in patients with cerebrovascular disease has not yet been reported. However, cerebrovascular disease seems to act in conjunction with other comorbidities, such as cardiovascular problems (Pranata et al., 2020).

Current studies have shown that cancer patients infected with SARS-CoV-2 were more likely to have intubation and mortality when compared to patients without cancer (Venkatesulu et al., 2020). Analysing severity and mortality, our metaanalysis showed that cancer patients had approximately a 2-fold increased risk of mortality during hospitalization for COVID19. However, no association was found between cancer patients and severe COVID-19 in our analysis. Venkatesulu et al. (2020) reported that cancer patients were associated with a 2.58, 2.18, 2.43, 2.54-fold higher risk of severity, ICU admission, intubation and mortality during SARS-Cov-2 infection, respectively. Moreover, the authors found that hematologic cancer was associated with a 2.39-fold increased risk of death from COVID-19, but this association was not found in lung, gastrointestinal and breast cancers (Venkatesulu et al., 2020). Several factors may contribute to elevated complications during the pathogenesis of COVID-19 in cancer patients, such as anticancer therapy, immunocompromised state, and other physiologic alteration, depending on the type of cancer (Gosain et al., 2020; Zhang et al., 2020e). Chemotherapy, for example, affects cells of the immune system causing immunosuppression, favoring COVID-19 morbidity (Bersanelli, 2020).

Previous meta-analyses have evaluated the influence of comorbidities on susceptibility to COVID-19. However, our meta-analysis included a considerable number of studies (48 articles) and patients with COVID-19 ( $\mathrm{n}=344,290)$. The limitations of this study were: (1) presence of publication bias in some analysis; (2) detection of heterogeneity among the metaanalysed studies; (3) low sample number in some comorbidities; (4) lack of detailed information on patients' comorbidities in the included studies, and (5) the small sample size in some studies. (TNR font 10 - justified - space 1,5).

\section{Conclusion}

In conclusion, our meta-analysis showed sufficient evidence that hypertension, diabetes, cardiovascular, chronic pulmonary, chronic kidney and cerebrovascular diseases increase the risk of severity and mortality in COVID-19 patients. In addition, malignancy showed increase the risk of death by COVID-19. Therefore, we suggest that the mentioned comorbidities may be an important predictor of an unfavourable outcome for COVID-19, contributing to the prognosis of severe cases of the disease.

We suggest that future studies may assess the risk and severity of mortality in individuals who have two or more preexisting comorbidities combined. The quantity of pre-existing comorbidity in an individual may be proportional to clinical complications caused by COVID-19. Therefore, it would be important to assess this condition to clarify which specific comorbidities combined can further increase the risk of the disease. 


\section{Conflicts of interest}

All authors declare that there are no conflicts of interest.

\section{Acknowledgments}

The authors grateful to the Universidade Federal de Alagoas - UFAL, Instituto de Ciências Biológicas e da Saúde ICBS, Programa de Pós-Gradução em Ciências da Saúde - PPGCS, and Coordenação de Aperfeiçoamento de Pessoal de Nível Superior - CAPES, for having contributed to the elaboration of this article.

\section{References}

Abd El-Aziz, T. M., \& Stockand, J. D. (2020). Recent progress and challenges in drug development against COVID-19 coronavirus (SARS-CoV-2) - an update on the status. In Infection, Genetics and Evolution (Vol. 83, p. 104327). Elsevier. https://doi.org/10.1016/j.meegid.2020.104327

Adapa, S., Chenna, A., Balla, M., Merugu, G. P., Koduri, N. M., Daggubati, S. R., Gayam, V., Naramala, S., \& Konala, V. M. (2020). COVID-19 Pandemic Causing Acute Kidney Injury and Impact on Patients With Chronic Kidney Disease and Renal Transplantation. Journal of Clinical Medicine Research. https://doi.org/10.14740/jocmr4200

Aggarwal, G., Cheruiyot, I., Aggarwal, S., Wong, J., Lippi, G., Lavie, C. J., Henry, B. M., \& Sanchis-Gomar, F. (2020). Association of Cardiovascular Disease With Coronavirus Disease 2019 (COVID-19) Severity: A Meta-Analysis. Current Problems in Cardiology, $45(8)$, 100617. https://doi.org/10.1016/j.cpcardiol.2020.100617

Alhazzani, W., Møller, M. H., Arabi, Y. M., Loeb, M., Gong, M. N., Fan, E., Oczkowski, S., Levy, M. M., Derde, L., Dzierba, A., Du, B., Aboodi, M., Wunsch, H., Cecconi, M., Koh, Y., Chertow, D. S., Maitland, K., Alshamsi, F., Belley-Cote, E., \& Rhodes, A. (2020). Surviving Sepsis Campaign: Guidelines on the Management of Critically Ill Adults with Coronavirus Disease 2019 (COVID-19). Critical Care Medicine, E440-E469. https://doi.org/10.1097/CCM.0000000000004363

Azkur, A. K., Akdis, M., Azkur, D., Sokolowska, M., van de Veen, W., Brüggen, M. C., O’Mahony, L., Gao, Y., Nadeau, K., \& Akdis, C. A. (2020). Immune response to SARS-CoV-2 and mechanisms of immunopathological changes in COVID-19. In Allergy: European Journal of Allergy and Clinical Immunology (75(7), 1564-1581). Wiley Online Library. https://doi.org/10.1111/all.14364

Babitt, J. L., \& Lin, H. Y. (2012). Mechanisms of anemia in CKD. Journal of the American Society of Nephrology, 23(10), 1631-1634. https://doi.org/10.1681/ASN.2011111078

Bersanelli, M. (2020). Controversies about COVID-19 and anticancer treatment with immune checkpoint inhibitors. Immunotherapy, 12(5), 269-273. https://doi.org/10.2217/imt-2020-0067

Charlotte, P., Gaël, G., Huu, T. H. P. P., Marine, B., Guillaume, C., Hatem, K., Véronique, E., Christian, C., Daniel, H., \& Govind, S. (2020). Characteristics, comorbidities, 30-day outcome and in-hospital mortality of patients hospitalised with COVID-19 in a Swiss area - a retrospective cohort study. Swiss Medical Weekly, 50(2930). https://doi.org/10.4414/smw.2020.20314

Chen, F., Fang, Z., M., Liu, Y., Zhang, Y., Zhang, K., Su, D. zhen, Meng, X., \& Zhang, Y. (2020d). The characteristics and outcomes of 681 severe cases with COVID-19 in China. Journal of Critical Care, 60, 32-37. https://doi.org/10.1016/j.jcrc.2020.07.003

Chen, T. L., Dai, Z., Mo, P., Li, X., Ma, Z., Song, S., Chen, X., Luo, M., Liang, K., Gao, S., Zhang, Y., Deng, L., \& Xiong, Y. (2020b). Clinical characteristics and outcomes of older patients with coronavirus disease 2019 (COVID-19) in Wuhan, China (2019): a single-centered, retrospective study. The Journals of Gerontology. Series A, Biological Sciences and Medical Sciences, 75(9), 1788-1795. https://doi.org/10.1093/gerona/glaa089

Chen, T., Wu, D., Chen, H., Yan, W., Yang, D., Chen, G., Ma, K., Xu, D., Yu, H., Wang, H., Wang, T., Guo, W., Chen, J., Ding, C., Zhang, X., Huang, J., Han, M., Li, S., Luo, X., \& Ning, Q. (2020c). Clinical characteristics of 113 deceased patients with coronavirus disease 2019: Retrospective study. The BMJ, 368. https://doi.org/10.1136/bmj.m1091

Chen, X., Zhao, B., Qu, Y., Chen, Y., Xiong, J., Feng, Y., Men, D., Huang, Q., Liu, Y., Yang, B., Ding, J., \& Li, F. (2020a). Detectable Serum Severe Acute Respiratory Syndrome Coronavirus 2 Viral Load (RNAemia) Is Closely Correlated With Drastically Elevated Interleukin 6 Level in Critically Ill Patients With Coronavirus Disease 2019. Clinical Infectious Diseases. https://doi.org/10.1093/cid/ciaa449

Daccord, C., Touilloux, B., \& Von Garnier, C. (2020). Asthma and COPD management during the COVID-19 pandemic. Revue Medicale Suisse, 16(692), 933-938.

Dang, J. z., Zhu, G. y., Yang, Y. J., \& Zheng, F. (2020). Clinical characteristics of coronavirus disease 2019 in patients aged 80 years and older. Journal of Integrative Medicine, 18(5), 395-400. https://doi.org/10.1016/j.joim.2020.07.002

de la Rica, R., Borges, M., Aranda, M., Del Castillo, A., Socias, A., Payeras, A., Rialp, G., Socias, L., Masmiquel, L., \& Gonzalez-Freire, M. (2020). Low albumin levels are associated with poorer outcomes in a case series of COVID-19 patients in Spain: A retrospective cohort study. Microorganisms. https://doi.org/10.3390/microorganisms8081106

de Moura, E. L., dos Santos, A. C. M., da Silva, D. M., dos Santos, B. B., Figueredo, D. de S., Moura, A. W. A., da Silva, A. F., Tanabe, I. S. B., de Lira Tanabe, E. L., Lira Neto, A. B., Pereira e Silva, A. C., de Carvalho Fraga, C. A., de Lima Filho, J. L., de Farias, K. F., \& Martins de Souza, E. V. (2020). 
Association of Polymorphisms in Cytokine genes with susceptibility to Precancerous Lesions and Cervical Cancer: A systematic review with meta-analysis. In Immunological Investigations. https://doi.org/10.1080/08820139.2020.1778023

Deng, Y., Liu, W., Liu, K., Fang, Y. Y., Shang, J., Zhou, L., Wang, K., Leng, F., Wei, S., Chen, L., \& Liu, H. G. (2020). Clinical characteristics of fatal and recovered cases of coronavirus disease 2019 (COVID-19) in Wuhan, China: a retrospective study. Chinese Medical Journal, 133(11), 1261-1267. https://doi.org/10.1097/CM9.0000000000000824

Drawz, P. E., Alper, A. B., Anderson, A. H., Brecklin, C. S., Charleston, J., Chen, J., Deo, R., Fischer, M. J., He, J., Hsu, C. Y., Huan, Y., Keane, M. G., Kusek, J. W., Makos, G. K., Miller, E. R., Soliman, E. Z., Steigerwalt, S. P., Taliercio, J. J., Townsend, R. R., ... Ojo, A. (2016). Masked hypertension and elevated nighttime blood pressure in CKD: Prevalence and association with target organ damage. Clinical Journal of the American Society of Nephrology, 11(4), 642-652. https://doi.org/10.2215/CJN.08530815

Fan, C., Li, K., Ding, Y., Lu, W. L., \& Wang, J. (2020). ACE2 Expression in Kidney and Testis May Cause Kidney and Testis Damage After 2019-nCoV Infection. MedRxiv. https://doi.org/10.1101/2020.02.12.20022418

Fang, H., Liu, Q., Xi, M., Xiong, D., He, J., Luo, P., \& Li, Z. (2020). Impact of comorbidities on clinical prognosis in 1280 patients with different types of COVID-19. Journal of Investigative Medicine. https://doi.org/10.1136/jim-2020-001555

Feng, Y., Ling, Y., Bai, T., Xie, Y., Huang, J., Li, J., Xiong, W., Yang, D., Chen, R., Lu, F., Lu, Y., Liu, X., Chen, Y., Li, X., Li, Y., Summah, H. D., Lin, H., Yan, J., Zhou, M., ... Qu, J. (2020). COVID-19 with Different Severities: A Multicenter Study of Clinical Features. American Journal of Respiratory and Critical Care Medicine, 201(11), 1380-1388. https://doi.org/10.1164/rccm.202002-0445OC

Gosain, R., Abdou, Y., Singh, A., Rana, N., Puzanov, I., \& Ernstoff, M. S. (2020). COVID-19 and Cancer: a Comprehensive Review. Current Oncology Reports, 22(5), 53. https://doi.org/10.1007/s11912-020-00934-7

Guan, W., Ni, Z., Hu, Y., Liang, W., Ou, C., He, J., Liu, L., Shan, H., Lei, C., Hui, D. S. C., Du, B., Li, L., Zeng, G., Yuen, K. Y., Chen, R., Tang, C., Wang, T., Chen, P., Xiang, J., ... Zhong, N. (2020). Clinical characteristics of coronavirus disease 2019 in China. New England Journal of Medicine, 382(18), 17081720. https://doi.org/10.1056/NEJMoa2002032

Guisado-Vasco, P., Valderas-Ortega, S., Carralón-González, M. M., Roda-Santacruz, A., González-Cortijo, L., Sotres-Fernández, G., Martí-Ballesteros, E. M., Luque-Pinilla, J. M., Almagro-Casado, E., La Coma-Lanuza, F. J., Barrena-Puertas, R., Malo-Benages, E. J., Monforte-Gómez, M. J., Diez-Munar, R., Merino-Lanza, E., Comeche-Casanova, L., Remirez-de-Esparza-Otero, M., Correyero-Plaza, M., Recio-Rodríguez, M., \& Carnevali-Ruiz, D. (2020). Clinical characteristics and outcomes among hospitalized adults with severe COVID-19 admitted to a tertiary medical center and receiving antiviral, antimalarials, glucocorticoids, or immunomodulation with tocilizumab or cyclosporine: A retrospective obser. EClinicalMedicine, 100591. https://doi.org/10.1016/j.eclinm.2020.100591

Harwood, R., \& Sinha, I. (2020). Diagnosis of COVID-19 in children: The story evolves. In BMC Medicine (Vol. 18, Issue 1, pp. 1-3). BioMed Central. https://doi.org/10.1186/s12916-020-01631-9

He, Fang, Ding, X. F., Cao, M., Gong, H. Y., Fu, X. Z., Luo, J., Liu, K., Tian, Z. Z., Luo, L., Fan, Y. Y., Li, T., Yao, Q. J., Chen, X. J., Duan, X. L., Chen, L., \& Jiang, L. (2020b). Comparative Analysis of 95 Patients with Different Severity in the Early Outbreak of COVID-19 in Wuhan, China. Canadian Journal of Infectious Diseases and Medical Microbiology, 2020. https://doi.org/10.1155/2020/4783062

He, Feng, Luo, Q., Lei, M., Fan, L., Shao, X., Huang, G., Zeng, J., Zhao, Z., Qin, S., Yang, Z., Yu, N., Yang, L., \& Cao, J. (2020a). Risk factors for severe cases of COVID-19: A retrospective cohort study. Aging, 12(15), 15730. https://doi.org/10.18632/AGING.103803

Higgins, J. P. T., \& Thompson, S. G. (2002). Quantifying heterogeneity in a meta-analysis. Statistics in Medicine. https://doi.org/10.1002/sim.1186 Hu, H., Yao, N., \& Qiu, Y. (2020). Comparing rapid scoring systems in mortality prediction of critical ill patients with novel coronavirus disease. Academic Emergency Medicine, 27(6), 461-468. https://doi.org/10.1111/acem.13992

Huang, C., Wang, Y., Li, X., Ren, L., Zhao, J., Hu, Y., Zhang, L., Fan, G., Xu, J., Gu, X., Cheng, Z., Yu, T., Xia, J., Wei, Y., Wu, W., Xie, X., Yin, W., Li, H., Liu, M., ... Cao, B. (2020). Clinical features of patients infected with 2019 novel coronavirus in Wuhan, China. The Lancet. https://doi.org/10.1016/S01406736(20)30183-5

Imig, J. D., \& Ryan, M. J. (2013). Immune and inflammatory role in renal disease. Comprehensive Physiology, 3(2), 957-976. https://doi.org/10.1002/cphy.c120028

Jain, V., \& Yuan, J. M. (2020). Predictive symptoms and comorbidities for severe COVID-19 and intensive care unit admission: a systematic review and metaanalysis. International Journal of Public Health, 65, 533-546. https://doi.org/10.1007/s00038-020-01390-7

Javanian, M., Bayani, M., Shokri, M., Sadeghi-Haddad-Zavareh, M., Babazadeh, A., Yeganeh, B., Mohseni, S., Mehraeen, R., Sepidarkish, M., Bijani, A., Rostami, A., Shahbazi, M., Tabari, A. M., Shabani, A., Masrour-Roudsari, J., Hasanpour, A. H., Gholinejad, H. E., Ghorbani, H., \& Ebrahimpour, S. (2020). Clinical and laboratory findings from patients with COVID-19 pneumonia in Babol North of Iran: a retrospective cohort study. Romanian Journal of Internal Medicine = Revue Roumaine de Medecine Interne, 58(3), 161-167. https://doi.org/10.2478/rjim-2020-0013

Jiang, Y., He, S., Zhang, C., Wang, X., Chen, X., Jin, Y., He, Z., Cai, M., Lin, Z., Ying, L., Mou, J., Zhao, H., Lin, R., Zhang, S., Wu, X., Chen, H., \& Lv, D. (2020). Clinical characteristics of 60 discharged cases of 2019 novel coronavirus-infected pneumonia in Taizhou, China. Annals of Translational Medicine, 8(8), 547. https://doi.org/10.21037/atm.2020.04.20

Jin, A., Yan, B., Hua, W., Feng, D., Xu, B., Liang, L., \& Guo, C. (2020). Clinical characteristics of patients diagnosed with COVID-19 in Beijing. Biosafety and Health, 2(2), 104-111. https://doi.org/10.1016/j.bsheal.2020.05.003

Lai, C. C., Liu, Y. H., Wang, C. Y., Wang, Y. H., Hsueh, S. C., Yen, M. Y., Ko, W. C., \& Hsueh, P. R. (2020). Asymptomatic carrier state, acute respiratory disease, and pneumonia due to severe acute respiratory syndrome coronavirus 2 (SARS-CoV-2): Facts and myths. In Journal of Microbiology, Immunology and Infection (53(3), 404-412). Elsevier. https://doi.org/10.1016/j.jmii.2020.02.012 
Lee, P. I., Hu, Y. L., Chen, P. Y., Huang, Y. C., \& Hsueh, P. R. (2020). Are children less susceptible to COVID-19? Journal of Microbiology, Immunology and Infection, 53(3), 371-372. https://doi.org/10.1016/j.jmii.2020.02.011

Lee, S. E., \& Kim, Y. S. (2020). Clinical and radiological findings of coronavirus disease 2019 pneumonia: 51 Adult patients from a single center in Daegu, South Korea. Journal of the Korean Society of Radiology, 81(3), 591-603. https://doi.org/10.3348/JKSR.2020.81.3.591

Li, G., Zhou, C. liang, Ba, Y. ming, Wang, Y. ming, Song, B., Cheng, X. bin, Dong, Q. fen, Wang, L. lin, \& You, S. sha. (2020c). Nutritional risk and therapy for severe and critical COVID-19 patients: A multicenter retrospective observational study. Clinical Nutrition. https://doi.org/10.1016/j.clnu.2020.09.040

Li, L. quan, Huang, T., Wang, Y. qing, Wang, Z. ping, Liang, Y., Huang, T. bi, Zhang, H. yun, Sun, W., \& Wang, Y. (2020d). COVID-19 patients' clinical characteristics, discharge rate, and fatality rate of meta-analysis. In Journal of Medical Virology (92(6), 577-583). Wiley Online Library. https://doi.org/10.1002/jmv.25757

Li, T., Lu, L., Zhang, W., Tao, Y., Wang, L., Bao, J., Liu, B., \& Duan, J. (2020b). Clinical characteristics of 312 hospitalized older patients with COVID-19 in Wuhan, China. Archives of Gerontology and Geriatrics, 91, 104185. https://doi.org/10.1016/j.archger.2020.104185

Li, X., Xu, S., Yu, M., Wang, K., Tao, Y., Zhou, Y., Shi, J., Zhou, M., Wu, B., Yang, Z., Zhang, C., Yue, J., Zhang, Z., Renz, H., Liu, X., Xie, J., Xie, M., \& Zhao, J. (2020a). Risk factors for severity and mortality in adult COVID-19 inpatients in Wuhan. Journal of Allergy and Clinical Immunology, 146(1), 110118. https://doi.org/10.1016/j.jaci.2020.04.006

Li, Xintao, Guan, B., Su, T., Liu, W., Chen, M., Bin Waleed, K., Guan, X., Gary, T., \& Zhu, Z. (2020e). Impact of cardiovascular disease and cardiac injury on in-hospital mortality in patients with COVID-19: A systematic review and meta-analysis. Heart, 106(15), 1117-1118. https://doi.org/10.1136/heartjnl2020-317062

Li, Z., Wu, M., Yao, J., Guo, J., Liao, X., Song, S., Li, J., Duan, G., Zhou, Y., Wu, X., Zhou, Z., Wang, T., Hu, M., Chen, X., Fu, Y., Lei, C., Dong, H., Xu, C., Hu, Y., \& Yan, J. (2020f). Caution on Kidney Dysfunctions of COVID-19 Patients. SSRN Electronic Journal. https://doi.org/10.2139/ssrn.3559601

Liao, Y., Feng, Y., Wang, B., Wang, H., Huang, J., Wu, Y., Wu, Z., Chen, X., Yang, C., Fu, X., \& Sun, H. (2020). Clinical characteristics and prognostic factors of COVID-19 patients progression to severe: a retrospective, observational study. Aging, 12(19), 18853-18865. https://doi.org/10.18632/aging.103931

Lin, L., Lu, L., Cao, W., \& Li, T. (2020b). Hypothesis for potential pathogenesis of SARS-CoV-2 infection-a review of immune changes in patients with viral pneumonia. In Emerging Microbes and Infections (9(1), 727-732). Taylor \& Francis. https://doi.org/10.1080/22221751.2020.1746199

Lin, Q., Zhao, S., Gao, D., Lou, Y., Yang, S., Musa, S. S., Wang, M. H., Cai, Y., Wang, W., Yang, L., \& He, D. (2020a). A conceptual model for the coronavirus disease 2019 (COVID-19) outbreak in Wuhan, China with individual reaction and governmental action. International Journal of Infectious Diseases, 93, 211-216. https://doi.org/10.1016/j.ijid.2020.02.058

Liu, F., Li, L., Xu, M. Da, Wu, J., Luo, D., Zhu, Y. S., Li, B. X., Song, X. Y., \& Zhou, X. (2020a). Prognostic value of interleukin-6, C-reactive protein, and procalcitonin in patients with COVID-19. Journal of Clinical Virology, 127, 104370. https://doi.org/10.1016/j.jcv.2020.104370

Liu, H., Chen, S., Liu, M., Nie, H., \& Lu, H. (2020c). Comorbid Chronic Diseases are Strongly Correlated with Disease Severity among COVID-19 Patients: A Systematic Review and Meta-Analysis. Aging and Disease, 11(3), 668. https://doi.org/10.14336/ad.2020.0502

Liu, Z., Jin, C., Wu, C. C., Liang, T., Zhao, H., Wang, Y., Wang, Z., Li, F., Zhou, J., Cai, S., Zeng, L., \& Yang, J. (2020b). Association between initial chest CT or clinical features and clinical course in patients with coronavirus disease 2019 Pneumonia. Korean Journal of Radiology, 21(6), 736. https://doi.org/10.3348/kjr.2020.0171

Lv, Z., Cheng, S., Le, J., Huang, J., Feng, L., Zhang, B., \& Li, Y. (2020). Clinical characteristics and co-infections of 354 hospitalized patients with COVID19 in Wuhan, China: a retrospective cohort study. Microbes and Infection, 22(4-5), 195-199. https://doi.org/10.1016/j.micinf.2020.05.007

Moccia, F., Gerbino, A., Lionetti, V., Miragoli, M., Munaron, L. M., Pagliaro, P., Pasqua, T., Penna, C., Rocca, C., Samaja, M., \& Angelone, T. (2020). COVID-19-associated cardiovascular morbidity in older adults: a position paper from the Italian Society of Cardiovascular Researches. GeroScience, 42 , 1021-1049. https://doi.org/10.1007/s11357-020-00198-w

Moher, D., Liberati, A., Tetzlaff, J., Altman, D. G., Altman, D., Antes, G., Atkins, D., Barbour, V., Barrowman, N., Berlin, J. A., Clark, J., Clarke, M., Cook, D., D’Amico, R., Deeks, J. J., Devereaux, P. J., Dickersin, K., Egger, M., Ernst, E., \& Tugwell, P. (2009). Preferred reporting items for systematic reviews and meta-analyses: The PRISMA statement. In PLoS Medicine (p. e1000097). https://doi.org/10.1371/journal.pmed.1000097

Moore, H. B., Barrett, C. D., Moore, E. E., Jhunjhunwala, R., McIntyre, R. C., Moore, P. K., Wang, J., Hajizadeh, N., Talmor, D. S., Sauaia, A., \& Yaffe, M. B. (2020). Study of alteplase for respiratory failure in severe acute respiratory syndrome coronavirus 2/COVID-19: Study design of the phase IIa STARS trial. Research and Practice in Thrombosis and Haemostasis, 4(6), 984-996. https://doi.org/10.1002/rth2.12395

Morrison, A. R., Johnson, J. M., Griebe, K. M., Jones, M. C., Stine, J. J., Hencken, L. N., To, L., Bianchini, M. L., Vahia, A. T., Swiderek, J., Ramesh, M. S., Peters, M. A., \& Smith, Z. R. (2020). Clinical characteristics and predictors of survival in adults with coronavirus disease 2019 receiving tocilizumab. Journal of Autoimmunity, 114, 102512. https://doi.org/10.1016/j.jaut.2020.102512

Ñamendys-Silva, S. A., Alvarado-Ávila, P. E., Domínguez-Cherit, G., Rivero-Sigarroa, E., Sánchez-Hurtado, L. A., Gutiérrez-Villaseñor, A., RomeroGonzález, J. P., Rodríguez-Bautista, H., García-Briones, A., Garnica-Camacho, C. E., Cruz-Ruiz, N. G., González-Herrera, M. O., García-Guillén, F. J., Guerrero-Gutiérrez, M. A., Salmerón-González, J. D., Romero-Gutiérrez, L., Canto-Castro, J. L., \& Cervantes, V. H. (2020). Outcomes of patients with COVID-19 in the intensive care unit in Mexico: A multicenter observational study. Heart and Lung. https://doi.org/10.1016/j.hrtlng.2020.10.013

Nicodemus, K. K. (2008). Catmap: Case-control and TDT meta-analysis package. BMC Bioinformatics, 9(1), 130. https://doi.org/10.1186/1471-2105-9-130

Parra-Bracamonte, G. M., Lopez-Villalobos, N., \& Parra-Bracamonte, F. E. (2020). Clinical characteristics and risk factors for mortality of patients with COVID-19 in a large data set from Mexico. Annals of Epidemiology. https://doi.org/10.1016/j.annepidem.2020.08.005 
Pereira, A. S., Shitsuka, D. M., Parreira, F. J., \& Shitsuka, R. (2018). Metodologia da pesquisa científica. [e-book]. Santa Maria. Ed. UAB/NTE/UFSM. https://repositorio.ufsm.br/bitstream/handle/1/15824/Lic_Computacao_Metodologia-Pesquisa-Cientifica.pdf.

Pranata, R., Huang, I., Lim, M. A., Wahjoepramono, E. J., \& July, J. (2020). Impact of cerebrovascular and cardiovascular diseases on mortality and severity of COVID-19-systematic review, meta-analysis, and meta-regression. Journal of Stroke and Cerebrovascular Diseases, 29(8), 104949. https://doi.org/10.1016/j.jstrokecerebrovasdis.2020.104949

Raj, D. S., Pecoits-Filho, R., \& Kimmel, P. L. (2015). Inflammation in Chronic Kidney Disease. In Chronic Renal Disease. https://doi.org/10.1016/B978-0-12411602-3.00017-2

Rando, H. M., Greene, C. S., \& Robson, M. P. (2020). SARS-CoV-2 and COVID-19: An Evolving Review of Diagnostics and Therapeutics. Manubot. https://greenelab.github.io/covid19-review/

Robson, B. (2020). Computers and viral diseases. Preliminary bioinformatics studies on the design of a synthetic vaccine and a preventative peptidomimetic antagonist against the SARS-CoV-2 (2019-nCoV, COVID-19) coronavirus. Computers in Biology and Medicine, 119, 103670. https://doi.org/10.1016/j.compbiomed.2020.103670

Santos, C. M. D. C., Pimenta, C. A. D. M., \& Nobre, M. R. C. (2007). A estratégia PICO para a construção da pergunta de pesquisa e busca de evidências. Rev Latino-Am Enfermagem. https://doi.org/10.1590/S0104-11692007000300023

Shang, Y., Liu, T., Wei, Y., Li, J., Shao, L., Liu, M., Zhang, Y., Zhao, Z., Xu, H., Peng, Z., Zhou, F., \& Wang, X. (2020). Scoring systems for predicting mortality for severe patients with COVID-19. EClinicalMedicine, 24, 100426. https://doi.org/10.1016/j.eclinm.2020.100426

Shi, P., Ren, G., Yang, J., Li, Z., Deng, S., Li, M., Wang, S., Xu, X., Chen, F., Li, Y., Li, C., Yang, X., Xie, Z., Wu, Z., \& Chen, M. (2020a). Clinical characteristics of imported and second-generation coronavirus disease 2019 (COVID-19) cases in Shaanxi outside Wuhan, China: A multicentre retrospective study. Epidemiology and Infection, 148. https://doi.org/10.1017/S0950268820002332

Shi, Y., Tan, M., Chen, X., Liu, Y., Huang, J., Ou, J., \& Deng, X. (2020b). Immunopathological characteristics of coronavirus disease 2019 cases in Guangzhou, China. MedRxiv. https://doi.org/10.1101/2020.03.12.20034736

Shu, L., Wang, X., Li, M., Chen, X., Ji, N., Shi, L., Wu, M., Deng, K., Wei, J., Wang, X., Cao, Y., Yan, J., \& Feng, G. (2020). Clinical characteristics of moderate COVID-19 patients aggravation in Wuhan Stadium Cabin Hospital: A 571 cases of retrospective cohort study. Journal of Medical Virology. https://doi.org/10.1002/jmv.26414

Stang, A. (2010). Critical evaluation of the Newcastle-Ottawa scale for the assessment of the quality of nonrandomized studies in meta-analyses. European Journal of Epidemiology, 25(9), 603-605. https://doi.org/10.1007/s10654-010-9491-z

Taghavi-Farahabadi, M., Mahmoudi, M., Soudi, S., \& Hashemi, S. M. (2020). Hypothesis for the management and treatment of the COVID-19-induced acute respiratory distress syndrome and lung injury using mesenchymal stem cell-derived exosomes. Medical Hypotheses, $144,109865$. https://doi.org/10.1016/j.mehy.2020.109865

Tay, M. Z., Poh, C. M., Rénia, L., MacAry, P. A., \& Ng, L. F. P. (2020). The trinity of COVID-19: immunity, inflammation and intervention. Nature Reviews Immunology, 20, 363-374. https://doi.org/doi.org/10.2217/imt-2020-0067

Tian, H., Liu, Y., Li, Y., Wu, C. H., Chen, B., Kraemer, M. U. G., Li, B., Cai, J., Xu, B., Yang, Q., Wang, B., Yang, P., Cui, Y., Song, Y., Zheng, P., Wang, Q., Bjornstad, O. N., Yang, R., Grenfell, B. T., ... Dye, C. (2020a). An investigation of transmission control measures during the first 50 days of the COVID19 epidemic in China. Science, 368(6491), 638-642. https://doi.org/10.1126/science.abb6105

Tian, W., Jiang, W., Yao, J., Nicholson, C. J., Li, R. H., Sigurslid, H. H., Wooster, L., Rotter, J. I., Guo, X., \& Malhotra, R. (2020b). Predictors of mortality in hospitalized COVID-19 patients: A systematic review and meta-analysis. Journal of Medical Virology, 92, 1875-1883. https://doi.org/10.1002/jmv.26050

Vena, A., Giacobbe, D. R., Di Biagio, A., Mikulska, M., Taramasso, L., De Maria, A., Ball, L., Brunetti, I., Loconte, M., Patroniti, N. A., Robba, C., Delfino, E., Dentone, C., Magnasco, L., Nicolini, L., Toscanini, F., Bavastro, M., Cerchiaro, M., Barisione, E., \& Caglieris, S. (2020). Clinical characteristics, management and in-hospital mortality of patients with coronavirus disease 2019 in Genoa, Italy. Clinical Microbiology and Infection, 26(11), 1537-1544. https://doi.org/10.1016/j.cmi.2020.07.049

Venkatesulu, B. P., Chandrasekar, V. T., Girdhar, P., Advani, P., Sharma, A., Elumalai, T., Hsieh, C., Elghazawy, H. I., Verma, V., \& Krishnan, S. (2020). A systematic review and meta-analysis of cancer patients affected by a novel coronavirus. MedRxiv: The Preprint Server for Health Sciences. https://doi.org/10.1101/2020.05.27.20115303

Wang, B., Li, R., Lu, Z., \& Huang, Y. (2020d). Does comorbidity increase the risk of patients with covid-19: Evidence from meta-analysis. Aging, 12(7), 6049. https://doi.org/10.18632/AGING.103000

Wang, D., Hu, B., Hu, C., Zhu, F., Liu, X., Zhang, J., Wang, B., Xiang, H., Cheng, Z., Xiong, Y., Zhao, Y., Li, Y., Wang, X., \& Peng, Z. (2020a). Clinical Characteristics of 138 Hospitalized Patients with 2019 Novel Coronavirus-Infected Pneumonia in Wuhan, China. JAMA - Journal of the American Medical Association, 323(11), 1061-1069. https://doi.org/10.1001/jama.2020.1585

Wang, G., Wu, C., Zhang, Q., Wu, F., Yu, B., Lv, J., Li, Y., Li, T., Zhang, S., Wu, C., Wu, G., \& Zhong, Y. (2020c). C-reactive protein level may predict the risk of COVID-19 aggravation. Open Forum Infectious Diseases, 7(5), ofaa153. https://doi.org/10.1093/ofid/ofaa153

Wang, X., Fang, J., Zhu, Y., Chen, L., Ding, F., Zhou, R., Ge, L., Wang, F., Chen, Q., Zhang, Y., \& Zhao, Q. (2020b). Clinical characteristics of non-critically ill patients with novel coronavirus infection (COVID-19) in a Fangcang Hospital. Clinical Microbiology and Infection, 26(8), 1063-1068. https://doi.org/10.1016/j.cmi.2020.03.032 
Wang, X., Fang, X., Cai, Z., Wu, X., Gao, X., Min, J., \& Wang, F. (2020e). Comorbid Chronic Diseases and Acute Organ Injuries Are Strongly Correlated with Disease Severity and Mortality among COVID-19 Patients: A Systemic Review and Meta-Analysis. Research, 2020 , 2402961. https://doi.org/10.34133/2020/2402961

Wu, C., Chen, X., Cai, Y., Xia, J., Zhou, X., Xu, S., Huang, H., Zhang, L., Zhou, X., Du, C., Zhang, Y., Song, J., Wang, S., Chao, Y., Yang, Z., Xu, J., Zhou, X., Chen, D., Xiong, W., \& Song, Y. (2020a). Risk Factors Associated with Acute Respiratory Distress Syndrome and Death in Patients with Coronavirus Disease 2019 Pneumonia in Wuhan, China. JAMA Internal Medicine, 180(7), 934-943. https://doi.org/10.1001/jamainternmed.2020.0994

Wu, J., Zhang, J., Sun, X., Wang, L., Xu, Y., Zhang, Y., Liu, X., \& Dong, C. (2020b). Influence of diabetes mellitus on the severity and fatality of SARS-CoV -2 infection. Diabetes, Obesity and Metabolism, 22(10), 1907-1914. https://doi.org/10.1111/dom.14105

Xie, H., Zhao, J., Lian, N., Lin, S., Xie, Q., \& Zhuo, H. (2020a). Clinical characteristics of non-ICU hospitalized patients with coronavirus disease 2019 and liver injury: A retrospective study. Liver International, 40(6), 1321-1326. https://doi.org/10.1111/liv.14449

Xie, J., Wu, W., Li, S., Hu, Y., Hu, M., Li, J., Yang, Y., Huang, T., Zheng, K., Wang, Y., Kang, H., Huang, Y., Jiang, L., Zhang, W., Zhong, M., Sang, L., Zheng, X., Pan, C., Zheng, R., \& Du, B. (2020b). Clinical characteristics and outcomes of critically ill patients with novel coronavirus infectious disease (COVID-19) in China: a retrospective multicenter study. Intensive Care Medicine. https://doi.org/10.1007/s00134-020-06211-2

Yang, J. K., Feng, Y., Yuan, M. Y., Yuan, S. Y., Fu, H. J., Wu, B. Y., Sun, G. Z., Yang, G. R., Zhang, X. L., Wang, L., Xu, X., Xu, X. P., \& Chan, J. C. N. (2006d). Plasma glucose levels and diabetes are independent predictors for mortality and morbidity in patients with SARS. Diabetic Medicine, 23(6), 623-628. https://doi.org/10.1111/j.1464-5491.2006.01861.x

Yang, J., Zheng, Y., Gou, X., Pu, K., Chen, Z., Guo, Q., Ji, R., Wang, H., Wang, Y., \& Zhou, Y. (2020a). Prevalence of comorbidities and its effects in coronavirus disease 2019 patients: A systematic review and meta-analysis. International Journal of Infectious Diseases, 94, 91-95. https://doi.org/10.1016/j.ijid.2020.03.017

Yang, J., Zheng, Y., Gou, X., Pu, K., Chen, Z., Guo, Q., Ji, R., Wang, H., Wang, Y., \& Zhou, Y. (2020b). Prevalence of comorbidities and its effects in patients infected with SARS-CoV-2: a systematic review and meta-analysis. International Journal of Infectious Diseases, 94, 91-95.

Yang, R., Gui, X., Zhang, Y., \& Xiong, Y. (2020c). The role of essential organ-based comorbidities in the prognosis of COVID-19 infection patients. Expert Review of Respiratory Medicine, 14(8), 835-838. https://doi.org/10.1080/17476348.2020.1761791

Yao, Q., Wang, P., Wang, X., Qie, G., Meng, M., Tong, X., Bai, X., Ding, M., Liu, W., Liu, K., \& Chu, Y. (2020). A retrospective study of risk factors for severe acute respiratory syndrome coronavirus 2 infections in hospitalized adult patients. Polish Archives of Internal Medicine, 130(5), 390-399. https://doi.org/10.20452/pamw.15312

Zhang, H., Cao, X., Kong, M., Mao, X., Huang, L., He, P., Pan, S., Li, J., \& Lu, Z. (2020c). Clinical and hematological characteristics of 88 patients with COVID-19. International Journal of Laboratory Hematology, 42(6), 780-787. https://doi.org/10.1111/ijlh.13291

Zhang, Jin jin, Dong, X., Cao, Y. yuan, Yuan, Y. dong, Yang, Y. bin, Yan, Y. qin, Akdis, C. A., \& Gao, Y. dong. (2020a). Clinical characteristics of 140 patients infected with SARS-CoV-2 in Wuhan, China. Allergy: European Journal of Allergy and Clinical Immunology, 75(7), 1730-1741. https://doi.org/10.1111/all.14238

Zhang, Jingqi, Wu, J., Sun, X., Xue, H., Shao, J., Cai, W., Jing, Y., Yue, M., \& Dong, C. (2020d). Associations of hypertension with the severity and fatality of SARS-CoV-2 infection: A meta-Analysis. Epidemiology and Infection, 148(e106), 1-7. https://doi.org/10.1017/S095026882000117X

Zhang, Jun, Yu, M., Tong, S., Liu, L. Y., \& Tang, L. V. (2020b). Predictive factors for disease progression in hospitalized patients with coronavirus disease 2019 in Wuhan, China. Journal of Clinical Virology, 127, 104392. https://doi.org/10.1016/j.jcv.2020.104392

Zhang, L., Zhu, F., Xie, L., Wang, C., Wang, J., Chen, R., Jia, P., Guan, H. Q., Peng, L., Chen, Y., Peng, P., Zhang, P., Chu, Q., Shen, Q., Wang, Y., Xu, S. Y., Zhao, J. P., \& Zhou, M. (2020e). Clinical characteristics of COVID-19-infected cancer patients: a retrospective case study in three hospitals within Wuhan, China. Annals of Oncology, 31(7), 894-901. https://doi.org/10.1016/j.annonc.2020.03.296

Zhao, Q., Meng, M., Kumar, R., Wu, Y., Huang, J., Lian, N., Deng, Y., \& Lin, S. (2020). The impact of COPD and smoking history on the severity of Covid19: A systemic review and meta-analysis. Journal of Medical Virology, 92(10), 1915-1921. https://doi.org/10.1002/jmv.25889

Zheng, F., Tang, W., Li, H., Huang, Y. X., Xie, Y. L., \& Zhou, Z. G. (2020a). Clinical characteristics of 161 cases of corona virus disease 2019 (COVID-19) in Changsha. European Review for Medical and Pharmacological Sciences, 24(6), 3404-3410. https://doi.org/10.26355/eurrev_202003_20711

Zheng, Y.-Y., Ma, Y.-T., Zhang, J.-Y., \& Xie, X. (2020b). COVID-19 and the cardiovascular system. Nature Reviews Cardiology, 17(5), 259-260. https://doi.org/10.1038/s41569-020-0360-5

Zheng, Z., Peng, F., Xu, B., Zhao, J., Liu, H., Peng, J., Li, Q., Jiang, C., Zhou, Y., Liu, S., Ye, C., Zhang, P., Xing, Y., Guo, H., \& Tang, W. (2020c). Risk factors of critical \& mortal COVID-19 cases: A systematic literature review and meta-analysis. Journal of Infection, 81(2), e16-e21. https://doi.org/10.1016/j.jinf.2020.04.021

Zhou, F., Yu, T., Du, R., Fan, G., Liu, Y., Liu, Z., Xiang, J., Wang, Y., Song, B., Gu, X., Guan, L., Wei, Y., Li, H., Wu, X., Xu, J., Tu, S., Zhang, Y., Chen, H., \& Cao, B. (2020). Clinical course and risk factors for mortality of adult inpatients with COVID-19 in Wuhan, China: a retrospective cohort study. The Lancet, 395(10229), 1054-1062. https://doi.org/10.1016/S0140-6736(20)30566-3

Zhu, Z., Cai, T., Fan, L., Lou, K., Hua, X., Huang, Z., \& Gao, G. (2020). Clinical value of immune-inflammatory parameters to assess the severity of coronavirus disease 2019. International Journal of Infectious Diseases, 95, 332-339. https://doi.org/10.1016/j.ijid.2020.04.041 